\title{
FAKTOR-FAKTOR YANG MEMPENGARUHI NIAT MELAKUKAN PENGGELAPAN PAJAK
}

\section{(Berdasarkan Persepsi Wajib Pajak Orang Pribadi Yang Terdaftar Di Kantor Pelayanan Pajak Pratama Kabupaten Subang)}

\author{
Yuliani Karlina ${ }^{1}$, Asep Kurniawan ${ }^{2}$, Indah Umiyati ${ }^{3}$ \\ ${ }_{1}^{1}$ STIE Sutaatmadja, Subang - Indonesia \\ ykarlina05@gmail.com
}

\begin{tabular}{l} 
INFO ARTIKEL \\
\hline Histori Artikel : \\
Tgl. Masuk : 22 Januari 2021 \\
Tgl. Diterima : 13 Maret 2021 \\
Tersedia Online : 31 Maret 2021 \\
\hline Keywords: \\
Tax evasion, love of money, tax \\
system, tax justice, tax \\
discrimination, understanding \\
of taxation, tax sanctions, \\
religiosity.
\end{tabular}

\section{ABSTRAK/ABSTRACT} \begin{abstract}
to finance its development. In order to finance all the interests of the state in realizing a better national economy, an APBN (State Revenue and Expenditure Budget) is prepared. The taxation sector is the largest sector that contributes to the State Budget. However, in the implementation of tax revenue does not match the predetermined target, one of the causes of this is due to tax evasion by taxpayers.
\end{abstract}

Indonesia is a developing country that needs funds

This study aims to examine the factors that influence the intention to commit tax evasion. This research is a quantitative research with data collection techniques using a questionnaire distributed to taxpayers who are registered free workers at KPP Pratama Subang. The sample used in this study was 118 respondents using purposive sampling technique and an error rate of $5 \%$. The analysis technique uses multiple linear regression analysis.

The results showed that the coefficient of determination $R 2$ was 0.374 , which means that the dependent variable could be explained by the independent variable at $37.4 \%$ and the remaining $62.6 \%$ was explained by other variables. The results of this study conclude that partially the variable love of money, tax system, tax justice, tax discrimination, and tax sanctions has no effect on tax evasion, while the variable understanding of taxation has a negative effect on tax evasion and the variable religiosity has a negative effect on tax evasion. Simultaneously, the variable love of money, tax system, tax justice, tax discrimination, understanding of taxation, taxation sanctions and religiosity have an effect on the variable tax evasion.

\section{PENDAHULUAN}

Indonesia merupakan negara berkembang yang membutuhkan dana untuk membiayai pembangunannya. Untuk membiayai segala kepentingan negara serta untuk mewujudkan perekonomian nasional yang lebih baik maka disusunlah APBN (Anggaran Pendapatan dan Belanja Negara). Seluruh pendapatan yang diterima oleh negara serta belanja atau pengeluaran pemerintah setiap tahunnya tercatat didalam APBN. Pendapatan negara 
diperoleh dari dua sektor yaitu penerimaan dari sektor perpajakan dan penerimaan negara yang bukan pajak.

Sektor perpajakan merupakan sektor terbesar yang berkontribusi bagi APBN. Pajak mempunyai peranan penting bagi pembangun sebuah negara. Seluruh pengeluaran-pengeluaran negara yang digunakan untuk pembangunan nasioanl serta untuk membiayai infrastuktur umum seperti jalan, stasiun dan alat-alat transportasi dibiayai oleh pajak.

\section{Tabel 1}

Target dan Realisasi Penerimaan Pajak (dalam miliar Rupiah)

\begin{tabular}{|c|c|c|c|}
\hline Tahun & Target & Realisasi & Capaian \\
\hline 2015 & $1.294,26$ & $1.060,83$ & $81,96 \%$ \\
\hline 2016 & $1.355,20$ & $1.105,73$ & $81,59 \%$ \\
\hline 2017 & $1.283,57$ & $1.151,03$ & $89,67 \%$ \\
\hline 2018 & $1.424,00$ & $1.315,51$ & $92,24 \%$ \\
\hline 2019 & $1.577,56$ & 1332,06 & $84.44 \%$ \\
\hline
\end{tabular}

Sumber: Laporan Kinerja Direktorat Jenderal Pajak Tahun 2018

Berdasarkan pada tabel target dan realisasi penerimaan pajak Indonesia dapat diketahui bahwa pada setiap tahun selama 2015 sampai dengan 2019 realisasi penerimaan pajak di indonesia tidak maksimal atau tidak dapat mencapai target yang telah di rencanakan. Terdapat beberapa faktor yang dapat menyebabkan penerimaan tidak sesuai target yang dicapai atau kinerja pajak tidak maksimal, salah satu penyebab dari hal tersebut karena adanya penggelapan pajak yang dilakukan oleh wajib pajak.

Tabel 1

Penerimaan Pajak KPP PratamaSubang

(dalam rupiah)

\begin{tabular}{|c|c|}
\hline Tahun & Jumlah Penerimaan \\
\hline $\mathbf{2 0 1 5}$ & 852.393 .786 .400 \\
\hline $\mathbf{2 0 1 6}$ & 761.629 .132 .254 \\
\hline $\mathbf{2 0 1 7}$ & 789.722 .590 .616 \\
\hline $\mathbf{2 0 1 8}$ & 994.410 .333 .713 \\
\hline $\mathbf{2 0 1 9}$ & 932.807 .248 .173 \\
\hline
\end{tabular}

Sumber: KPP Pratama Subang
Berdasarkan pada tabel penerimaan pajak KPP Pratama Subang diatas dapat dilihat bahwa meskipun terjadi beberapa peningkatan pada tahun 2017 dan 2018 namun terjadi penurunan penerimaan pajak pada tahun 2016 dan 2019.

Dana pajak bersumber dari wajib pajak yang menyetorkan kewajiban pajaknya. Wajib pajak dibagi menjadi wajib pajak badan dan wajib pajak orang pribadi. Wajib pajak orang pribadi dapat dibagi menjadi wajib pajak orang pribadi yang memiliki penghasilan dari pekerjaan, wajib pajak orang pribadi yang melakukan pekerjaan bebas dan wajib pajak orang pribadi pengusaha. Untuk menunjang keberhasilan dalam melakukan pemungutan pajak maka suatu sistem sangat diperlukan. Sistem pembayaran pajak yang diterapkan di Indonesia saat ini yaitu self assessment system, sistem ini dapat mendorong perilaku penggelapan pajak. Wajib pajak diharuskan untuk melakukan perhitungan dan penyetoran pajak sendiri ke kantor pelayanan pajak (KPP).

Disatu sisi self asessment system dapat mendorong masyarakat untuk lebih aktif dan sadar dalam melakukan pembayaran pajak, karena sistem ini membuat pembayaran pajak menjadi lebih praktis. Di sisi lain, kepercayaan yang diberikan tersebut memberikan peluang bagi wajib pajak untuk merencanakan penggelapan pajak (tax evasion). Karena meski disatu sisi pajak sifatnya wajib namun pajak dipandang sebagai suatu beban yang akan mengurangi kemampuan ekonomis seseorang, karena sebagian dari total penghasilan yang mereka dapatkan harus disisihkan untuk membayar pajak. Padahal, uang yang dibayarkan untuk membayar pajak tersebut dapat digunakan untuk memenuhi keperluan hidup sehari-hari, jika tidak ada kewajiban pajak tersebut (Suminarsasi dan Supriyadi, 2011). Dengan adanya halhal tersebut niat untuk melakukan penggelapan pajak dapat muncul pada setiap individu wajib pajak.

Bebeberapa faktor-faktor yang dapat mempengaruhi penggelapan pajak salah satunya adalah karena kurangnya pemahaman mengenai perpajakan, 
sehingga akan ada kemungkinan wajib pajak melakukan pelanggaran karena kurangnya pemahaman baik itu mengenai fungsi pajak maupun sanksi yang akan dikenakan kepada wajib pajak jika melakukan pelanggaran.

Selanjutnya, ketika sanksi perpajakan telah ditetapkan oleh pemerintah tetapi tidak disosialisasikan kepada masyarakat juga dapat menjadi faktor yang menyebabkan seseorang melakukan penggelapan pajak. Terlebih jika sanksi perpajakan yang telah ditetapkan tersebut tidak membuat jera para pelanggar atau wajib pajak yang melakukan penggelapan pajak.

Religiusitas merupakan faktor lain yang dapat mempengaruhi perilaku etis individu, religiusitas ini dipercaya sebagai pencegah perilaku yang tidak etis atau pembentukan moral dan perilaku yang baik. Religiusitas dapat membatasi niatan individu atau wajib pajak untuk melakukan penggelapan pajak, karena religiusitas berlaku seperti sebuah penegakkan aturan-aturan yang dapat membatasi niatan individu atau wajib pajak untuk melakukan penggelapan pajak (Surahman dan Putra, 2018).

Berdasarkan penelitian terdahulu yang dilakukan oleh Suharman dan Putra (2018) dalam penelitiannya yang berjudul faktor-faktor wajib pajak terhadap etika penggelapan pajak menyatakan bahwa Love of Money tidak berpengaruh terhadap persepsi wajib pajak mengenai etika penggelapan pajak (tax evasion). Sedangkan menurut Asih dan Dwiyanti (2019) menyatakan bahwa Love of Money berpengaruh negatif terhadap persepsi etika penggelapan pajak pada wajib pajak orang pribadi.

Hasil pengujian hipotesis yang dilakukan oleh Reswina dan Zulvia (2018) menghasilkan nilai signifikan 0,000 $<0,05$ sehingga uji hipotesis pertama menyatakan bahwa terdapat pengaruh sistem perpajakan terhadap penggelapan pajak. Sedangkan hasil penelitian yang dilakukan oleh Tumewu dan Wahyuni (2018) menyatakan bahwa tidak terdapat pengaruh antara sistem perpajakan terhadap persepsi mahasiswa tentang penggelapan pajak.
Penelitian yang dilakukan oleh Pratiwi dan Prabowo (2019) menyatakan bahwa persepsi wajib pajak orang pribadi menunjukkan bahwa keadilan pajak memilki pengaruh terhadap persepsi wajib pajak orang pribadi mengenai penggelapan pajak. Sedangkan menurut Tumewu dan Wahyuni (2018) menyatakan bahwa variabel keadilan dalam perpajakan tidak berpengaruh kepada persepsi mahasiswa terhadap penggelapan pajak.

Tumewu dan Wahyuni (2018) dalam penelitiannya menyatakan bahwa variabel diskriminasi berpengaruh terhadap penggelapan pajak. Sedangkan dalam penelian yang dilakukan oleh Pratiwi dan Prabowo (2019) yang berjudul Keadilan dan Diskriminasi Pajak Terhadap Penggelapan Pajak: Persepsi Wajib Pajak Orang Pribadi menyatakan bahwa tidak terdapat pengaruh antara diskriminasi pajak terhadap persepsi wajib pajak orang pribadi mengenai penggelapan pajak.

Penelitian terdahulu yang dilakukan oleh Suharman dan Putra (2018) dalam penelitiannya yang berjudul Faktor-faktor wajib pajak terhadap etika penggelapan pajak menyatakan bahwa pemahaman perpajakan berpengaruh terhadap persepsi wajib pajak mengenai etika penggelapan pajak (tax evasion) Sedangkan menurut Yezzie (2017) bahwa tidak terdapat pengaruh antara Pemahaman Perpajakan dengan persepsi wajib pajak mengenai etika penggelapan pajak/ tax evasion .

Penelitian terdahulu yang dilakukan oleh Sundari (2019) menyatakan bahwa sanksi perpajakan berpengaruh terhadap persepsi wajib pajak mengenai penggelapan pajak (tax evasion). Sedangkan menurut Yezzie (2017) sanksi perpajakan tidak memiliki pengaruh terhadap persepsi wajib pajak mengenai etika penggelapan pajak/ Tax Evasion.

Penelitian terdahulu yang dilakukan oleh Mutia (2015) bahwa variabel religiusitas tidak berpengaruh pada etika penggelapan pajak. Sedangkan berdasarkan penelitian yang dilakukan oleh Suharman dan Putra (2018) dalam penelitiannya yang berjudul faktor-faktor wajib pajak terhadap etika 
penggelapan pajak menyatakan bahwa religiusitas berpengaruh terhadap persepsi wajib pajak mengenai penggelapan pajak (tax evasion). Hasil ini menjelaskan bahwa jika religiusitas tinggi keyakinan yang kuat pada agama mengurangi sikap untuk melakukan kecurangan pajak.

Berdasarkan beberapa hasil penelitian terdahulu yang masih bertentangan atau tidak sejalan, penulis tertarik untuk menguji kembali beberapa variabel dengan menggabungkan variabel keadilan, sistem perpajakan, diskiminasi perpajakan dan pemahaman perpajakan (Tumewu \& Wahyuni, 2018); Love Of Money dan Religiusitas (Surahman \& Putra,2018); serta sanksi perpajakan (Maghfiroh \& Fajarwati, 2016).

Perbedaan penelitian ini dengan penelitian sebelumnya yaitu mengenai penentuan populasi. Dalam penelitian ini populasi yang digunakan adalah wajib pajak orang pribadi yang melakukan pekerjaan bebas yang terdaftar di Kantor Pelayanan Pajak Pratama Kabupaten Subang.

Penelitian ini bertujuan untuk mengetahui pengaruh Love Of Money, sistem, keadilan, diskriminasi, pemahaman, sanksi dan religiusitas terhadap niat seseorang untuk melakukan penggelapan pajak.

\section{KERANGKA TEORITIS DAN PENGEMBANGAN HIPOTESIS}

\section{Landasan Teori \\ Theory Planned Of Behavior}

Teori ini memiliki fondasi terhadap perspektif kepercayaan yang mampu mempengaruhi seseorang untuk melakukan tindakan yang spesifik. Perspektif kepercayaan dilaksanakan melalui penggabungan beraneka ragam karateristik, kualitas dan atribut atas informasi tertentu yang kemudian membentuk kehendak dalam bertingkah laku (Yuliana, 2004). Keputusan dalam berlaku melalui cara yang dikehendaki atau stimulus untuk melaksanakan suatu tindakan baik secara sadar maupun tidak sadar disebut dengan Intensi (niat)
(Corsini, 2002). Awal terbentuknya perilaku seseorang dimulai dari intensi. Dalam menjelaskan perilaku apapun yang memerlukan perencanaan maka teori planned behavior ini cocok untuk diterapkan (Ajzen, 1991).

Planned behavior theory adalah perluasan dari reasoned action theory. Reasoned action theory memilki buktibukti ilmiah bahwa terdapat niat yang diakibatkan oleh dua alasan, yaitu norma subjektif dan sikap terhadap perilaku untuk melakukan tindakan atau perilaku tetentu (Fishbein dan Ajzen, 1975). Beberapa tahun kemudian, Ajzen (1988 menambahkan satu faktor lain yaitu kontrol perilaku persepsian individu atau perceived behavioral control. Keadaan faktor tersebut mengubah reasoned action theory menjadai planned behavior theory.

Planned behavior theory menjelaskan bahwa sikap terhadap perilaku merupakan pokok penting yang sanggup memperkirakan suatu perbuatan, meskipun demikian perlu dipertimbangkan sikap sesorang dalam menguji norma subjektif serta mengukur kontrol perilaku persepsian orang tersebut. Bila ada sikap yang positif, dukungan dari orang sekitar serta adanya persepsi kemudahan karena tidak ada hambatan untuk berperilaku maka niat sesorang untuk berperilaku akan semakin tinggi (Ajzen, 2005).

\section{Persepsi}

Azwar (2002) dalam Tumewu dan Wahyuni (2018), sikap adalah suatu bentuk evaluasi atau reaksi perasaan. Terbentuknya sikap menurt Katz et al. dalam Azwar (2002), merupakan respon koginitif yaitu tanggapan dari pandangan dan pernyataan manusia tentang apa yang dipercayainya. Mengenai sikap terhadap penggelapan pajak, meyakini bahwa penggelapan pajak adalah hal yang tidak etis (persepsi etika) sehingga dapat dipandang bahwa penggelapan pajak adalah sikap atau perilaku yang negatif.

\section{Pajak}

Pengertian pajak menurut UndangUndang no. 28 tahun 2007: Pajak adalah kontribusi wajib kepada negara, yang terutang oleh orang pribadi atau badan 
yang bersifat memaksa berdasarkan Undang-Undang, dengan tidak mendapatakan imbalan atau manfaat secara langsung dan digunakan untuk keperluan Negara bagi sebesar-besarnya kemakmuran rakyat.

Prof. Dr. Rochmat Soemitro, SH mendefinisikan pajak sebagai iuran yang diberikan masyarakat kepada kas negara dengan berdasarkan kepada undangundang yang berlaku (yang sifatnya dapat dipaksakan tetapi tidak mendapatkan jasa timbal balik (kontra pretasi) atau manfaat secara langsung dapat ditujukan dan dirasakan serta digunakan untuk membayar pengeluaran-pengeluaran yang bersifat umum.

\section{Wajib Pajak}

Berdasarkan pasal 1 UndangUndang Nomor 16 Tahun 2000 pengertian wajib pajak adalah orang pribadi atau badan, meliputi pembayar pajak, pemotong pajak, dan pemungut pajak, yang mempunyai hak dan kewajiban perpajakan sesuai dengan ketentuan perundang-undangan perpajakan. Rahayu (2006) membedakan wajib pajak menjadi 3, yaitu:

1. Wajib pajak orang pribadi terdiri dari usahawan maupun non usahawan;

2. Wajib pajak badan, yang meliputi perseroan terbatas, perseroan komanditer, perseroan lainnya, Badan Usaha Miliki Negara atau Daerah dengan nama dan dalam bentuk apapun, firma, kongsi, koperasi, dana pensiun, persekutuan, perkumpulan, yayasan, organisasi massa, organisasi sosial politik, atau organisasi sosial yang sejenis, lembaga, bentuk usaha tetap, dan bentuk badan lainnya; dan

3. Pemungut atau pemotong pajak yang ditunjuk oleh pemerintah, misalnya bendaharawan pemerintah dan Kantor Pembendaharaan dan Kas Negara (KPKN).

\section{Pekerjaan Bebas}

Definisi Pekerjaan Bebas menurut Pasal 1 Undang-Undang Nomor 28 Tahun 2007,Pekerjaan Bebas adalah pekerjaan yang dilakukan oleh orang pribadi yang mempunyai keahlian khusus sebagai usaha untuk memperoleh penghasilan yang tidak terikat oleh suatu hubungan kerja. Pekerjaan bebas sendiri umumnya terkait dengan keahlian atau profesi yang dijalankan sendiri oleh tenaga ahli yang bersangkutan seperti: dokter, pengaraca, konsultan, atau notaris. Pelaku pekerja bebas tersebut membuka praktek sendiri dengan menggunakan nama sendiri.

\section{Penggelapan pajak}

Suatu aktivitas yang dilakukan oleh wajib pajak dengan tujuan untuk meringankan atau mengurangi beban pajak dengan cara melanggar undangundang disebut juga dengan penggelapan pajak (tax evasion) (Mardiasmo, 2004). Menurut Pohan (2017) dalam Sundari (2019) penggelapan pajak (tax evasion) adalah usaha yang dilakukan oleh wajib pajak untuk menghindari pajak yang terutang dengan cara menyembunyikan keadaaan yang sebenarnya. Cara ini tidaklah aman bagi wajib pajak, karena cara atau teknik yang dilakukan oleh wajib pajak tersebut tidak dibenarkan dalam undang-undang dan peraturan perpajakan.

\section{Love Of Money}

Love of money adalah suatu cara dalam melakukan pengukuran terhadap nilai (value) seseorang atau keinginan mengenai uang akan tetapi bukan kebutuhan mereka dan makna atau pentingnya serta perilaku terhadap uang (Tang, 2004) dalam (Azziz, 2015). Seseorang yang memiliki kecintaan yang begitu besar terhadap uang, orang tersebut akan menempatkan uang sebagai hal yang sangat penting. Oleh karena itu, orang mempunyai kecintaan yang sangat besar pada uang akan berperilaku kurang etis dibandingkan dengan orang yang memunyai kecintaan terhadap uang yang lebih rendah (Tang, 2002) dalam Basri (2015).

\section{Sistem Perpajakan}

Sistem pajak yang digunakan di Indonesia yaitu self assessment system. Self assessment system ini mengharuskan wajib pajak berperan aktif dalam kegiatan perpajaknya. Menurut Pohan (2007) 
dalam Sundari (2019) self assessment system adalah suatu langkah-langkah pemungutan pajak dengan memberikan tugas kepercayaan dan tanggungjawab kepada individu wajib pajak untuk dapat melakukan sendiri kewajiban dan hak perpajakannya.

Sedangkan menurut resmi (2014) dalam Sundari (2019) menyatakan bahwa self assesment system adalah langkahlangkah atau tatacara pemungutan pajak dengan cara memberikan keuasaan atau kebebasan kepada wajib pajak dalam menentukan sendiri jumlah pajak yang terutang setiap tahunnya untuk dibayarkan kepada kas negara, tetapi harus sesuai dengan peraturan Undang-Undang perpajakan yang berlaku.

\section{Keadilan Perpajakan}

Di Indonesia, keadilan perpajakan dianggap sebagaia sesuatu yang berkaitan dengan hak dan kewajiban individu wajib pajak yang memiliki tujuan untuk menciptakan masyarakat yang adil dan makmur. Mardiasmo (2009) dalam Pratiwi dan Prabwo (2019) mengungkapkan bahwa untuk mencapai suatu keadilan, undang-undang yang dibuat atau disusun serta pelaksanaan pemungutan pajak harus adil dan juga harus sejalan dengan tujuan hukum. Dalam hal ini keadilan yang dimaksud dapat dilihat dalam kemampuan masyarakat atau wajib pajak dalam membayar pajak, apakah pemerintah sudah memberlakukan peraturan perpajakan secara umum dan merata.

Siahaan (2010) dalam Wahyuni (2018) menjelaskan bahwa dengan mengacu kepada aspek kedua yiatu kemampuan membayar dapat didapatkan kesimpulan bahwa terdapat dua kelompok dalam keadialan pajak:

\section{a. Keadilan Horizontal}

Orang-orang yang memiliki jumlah penghasilan atau kemampuan yang sama berarti jumlah pajak yang dibayarkan kepada negara juga dengan jumlah yang sama. Dengan demikian prinsip ini hanya menerapkan prinsip dasar keadilan berdasarkan undang-undang. Misalnya terdapat dua orang yang memiliki jumlah yang sama maka kedua orang tersebut saat melakukan pembayaran pajak, jumlah pajak yang dibayar oleh kedu orang tersebut jumlahnya sama.

b. Keadilan Vertikal

Prinsip keadilan vertikal memberi definisi bahwa orang-orang yang memiliki jumlah penghasilan atau kemampuan yang lebih besar maka jumlah pajak yang dibayar juga lebih besar dari orang yang jumlah penghasilannya lebih kecil dari mereka. Dalam hal ini berarti bahwa prinsip keadilan vertikal dan prinsip keadilan horizontal memberikan perlakuan yang sama, hanya saja pada keadilan horizontal, orang yang memiliki kemampuan atau jumlah penghasilan yang berbeda harus melakukan perpajakan dengan jumlah yang berbeda.

Siahaan (2010) dalam Wahyuni (2018) menjelasakan bahwa terdapat tiga aspek yang harus diperhatikan dalam perpajakan, yaitu:

1) keadilan dalam melakukan penyusunan Undang-Undang Pajak.

2) Keadilan dalam penerapan ketentuan perpajakan.

3) keadilan dalam penerapan ketentuan penggunaan uang pajak.

\section{Diskriminasi Perpajakan}

Berdasarkan Undang-Undang No. 39 Tahun 1999 tentang Hak Asasi Manusia Pasal 1 ayat (3), Undang-Undang tersebut menyatakan bahwa diskiriminasi adalah setiap pembatasan, pelecehan, atau pengucilan yang langsung ataupun tidak langsung didasarkan perbededaan manusia atas dasar agama, suku, ras, etnik, kelompok, golongan, status sosial, status ekonomi, jenis kelamin, bahasa, dan keyakinan politik, yang berakibat pengangguran, penyimpangan atau penghapusan pengakuan, pelaksanaan atau penggunaan hak asasi manusia dan kebebasan dasar dalam kehidupan, baik individual maupun kolektif dalam bidang politik, ekonomi, hukum, sosial, budaya dan aspek kehidupan yang lain.

$$
\text { Rahman Irma }
$$
mendefinisikan diskriminasi sebagai perbedaan perlakuan antar sesama umat manusia yang dilihat dari segi ras, agama, sosial, warna kulit dan lain-lain.Terkait 
dengan pengelapan pajak, dalam kondisi tertentu diskriminasi dipandang atau dianggap sebagai yang yang paling dibenarkan atau wajar dalam beberapa kasus tertentu. Misalnya yaitu ketika sistem perpajakan telah bertindak tidak adil, dan pajak yang terkumpul dari masyarakat tebuang sia-sia atau tidak digunakan dengan benar (Rahman, 2013). Diskriminasi dalam perpajakan merupakan kondisi dimana pemerintah memberikan pelayanan perpajakan yang tidak seimbang atau tidak merata terhadap masyarakat atau wajib pajak (Abrahams \& Kristanto, 2016). Terdapat contoh peraturan yang dianggap sebagai wujud dari diskriminasi yaitu adanya peraturan pemerintah nomor 60 tahun 2010 tentang zakat dan sumbangan keagamaan yang bersifat wajib yang bisa menjadi pengurang penghasilian bruto. Peraturan tersebut dianggap hanya akan menguntukan satu pihak saja, yaitu orang yang beragama islam, karena didalam agama mereka menyuruh untuk melaksanakan pajak. Sehingga jumlah penghasilan bruto yang didapatkan dapat dikurangi dengan jumlah zakat yang dilakukan, sehingga beban pajak yang diabayarkan menjadi berkurang (Indriyani, Masitoh dan Wahyuningsih, 2016).

\section{Pemahaman Perpajakan}

Resmi (2009) menjelaskan bahwa pengetahuan dan pemahaman mengenai peraturan perpajakan adalah langkahlangkah wajib pajak dalam memahami atau memaknai tentang perpajakan dan mengimplementasikan pengetahuan atau pemahaman itu dalam melakukan aktivitas perpajakan seperti membayar pajak.

Pemahaman perpajakan adalah adalah suatu proses atau langkah-langkah dimana wajib pajak mengetahui mengenai perpajakan dan menerapkan pengetahuannya mengenai perpajakan tersebut dalam melakukan aktivitas atau kegiatan perpajakan seperti membayar pajak, melaporkan SPT dan sebagainya (Ardiansyah, 2017).

\section{Sanksi Perpajakan}

Mardiasmo (2016) memberikan pejelasan tentang sanksi pajak, bahwa sanksi perpajakan didefinisikan sebagai jaminan mengenai ketentuan peraturan perundang undangan perpajakan (Norma Perpajakan) yang telah ditetapkan atau disusun dan akan dituruti/ditaati/dipatuhi oleh wajib pajak. Atau dengan kata lain dapat diartikan bahwa sanksi perpajakan dapat digunakan sebagai alat pencegah (preventif) agar wajib pajak enggan untuk melanggar norma perpajakan khususnya penggelapan pajak.

Menurut Sundari (2018), sanksi perpajakan diartikan sebagai suatu hukuman atas pelanggaran dalam dunia perpajakan yang dilakukan oleh wajib pajak yang melakukan pelanggaran. Sanksi perpajakan terdiri sanksi administrasi, yaitu sanksi dapat berupa bunga, denda dan kenaikan. Kemudian sanksi pidana yaitu sanksi berupa kurungan penjara.

\section{Religiusitas}

Agama adalah salah satu badan sosial yang paling umum yang memiliki pengaruh pada sikap masyarakat, nilainilai, dan perilaku baik pada tingkat individu maupun masyarakat. Keagamaan atau religiusitas dapat diwujudkan dalam berbagai sisi atau sudut-sudut kehidupan manusia (Mohlis, 2009) dalam (Fauzan, 2015).

Glock dan Stark (1966) dalam Ancok dan Suroso (2004) dalam Safitri (2018) mengatakan bahwa religiusitas adalah keseluruhan dari fungsi jiwa individu mencakup keyakinan, perasaan, dan perilaku yang diarahkan secara sadar dan sungguh-sungguh pada ajaran agamanya dengan mengerjakan lima dimensi keagamaan yang didalamnya mencakup tata cara ibadah wajib maupun sunat serta pengalaman dan pengetahuan agama dalam diri individu.

Adapun model kerangka pemikiran sebagai berikut: 


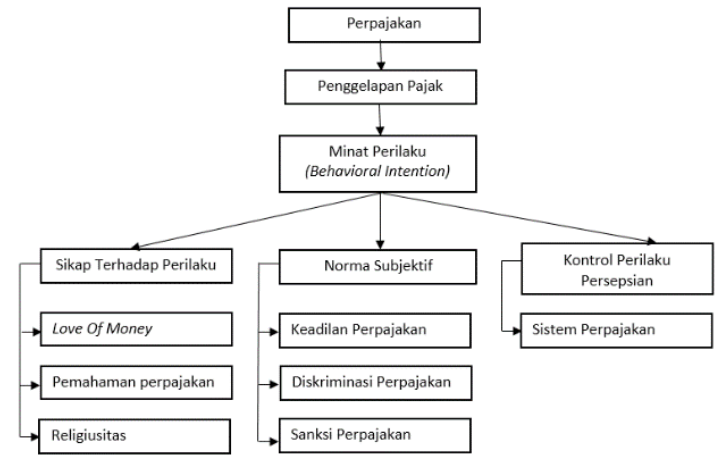

\section{Gambar 1 Kerangka Pemikiran \\ Sumber: Peneliti (2020)}

\section{Pengembangan Hipotesis}

1. Pengaruh love of money terhadap niat seseorang melakukan Penggelapan Pajak

Lau, Choe, dan Tan (2013) dalam

Rosianti dan Mangonting (2014) mengatakan bahwa ketika seseorang menempatkan uang sebagai prioritas paling penting dalam kehidupan sehariharinya, mereka akan merasa bahwa tax evasion atau penggelapan pajak adalah tindakan yang dapat diterima atau tindakan yang wajar untuk dilakukan. Hal tersebut sejalan dengan pendapat Tang \& Chiu (2003) bahwa orang-orang yang memiliki kecintaan terhadap uang yang sangat tinggi secara mental lebih banyak terlibat dalam perilaku tidak etis dalam organisasi.

Seseorang yang memiliki kecintaan yang sangat tinggi akan melakukan cara apapun agar kebutuhan hidupnya terpenuhi meskipun cara tersebut tidak etis. Beberapa peneliti mengusulkan bahwa cinta uang merupakan akar dari segala kejahatan. Asih dan Dwiyanti (2019), dalam penelitiannya menyatakan bahwa love of money berpengaruh negatif terhadap persepsi etika penggelapan pajak pada wajib pajak orang pribadi. Semakin tinggi sifat love of money yang dimiliki oleh individu wajib pajak, maka persepsi wajib pajak terhadap etika penggelapan pajak juga semakin tinggi, karena kecintaan terhadap uang yang sangat tinggi tersebut dapat membuat individu wajib pajak cenderung melakukan penggelapan pajak dan wajib pajak meandang perilaku tersebut sebagai perilaku yang etis atau dibenarkan. Penelitian tersebut sejalan dengan Lau, Tan dan Choe (2013) dalam Basri (2015) bahwa money ethic berhubungan negatif dengan etika tax evasion. Semakin tinggi money ethic maka semakin besar juga kemungkinan wajib pajak untuk berperilkau tidak etis atau melakukan penggelapan pajak. Dari uraian diatas maka dapat disimpulkan bahwa hipotesis pertama dalam penelitian ini adalah:

$\mathrm{H} 1$ : Love of money berpengaruh positif terhadap niat seseorang melakukan penggelapan pajak berdasarkan persepsi wajib pajak orang pribadi.

\section{Pengaruh Sistem Perpajakan terhadap niat seseorang melakukan Penggelapan Pajak}

Sistem perpajakan diartikan sebagai suatu sistem pemungutan atau pengumpulan pajak kepada wajib pajak yang merupakan perwujudan dari peran serta wajib pajak untuk secara langsung dan bersama-sama melaksanakan kewajibannya dalam melakukan aktivitas perpajakan termasuk membayar pajak yang diperlukan untuk pembiayaan penyelenggaraan negara dan pembangunan (Yuliyanti dkk, 2017). Sistem perpajakan yang digunakan di Indonesia yaitu Self Assessment System dimana sistem ini mewajibkan wajib pajak sendiri yang aktif dalam melakukan aktivitas perpajakan seperti menghitung, menyetor dan melaporkan kewajiban pajaknya. Sistem perpajakan dapat dikatakan baik apabila prosedur perpajakan terkait perhitungan pembayaran dan pelaporan dapat dilakukan dengan mudah. Selain itu fiskus harus berperan aktif dalam mengawasi dan melaksanakan tugasnya dengan integritas yang tinggi. Sebaliknya, sistem perpajakan dikatakan tidak baik apabila didalam pelaksanaannya kepastian kepada wajib pajak tentang berapa jumlah pajak yang terutang dan juga harus ada transparansi agar tidak terjadi kesewenangan dari fiskus atau pemungut pajak. Jadi semakin baik sistem perpajakan maka semakin rendah tingkat pengelapan pajak, Fhyel (2018). 
Hasil penelitian yang dilakukan oleh Fhyel (2018) bahwa sistem perpajakan berpengaruh negatif terhadap penggelapan pajak. Hal ini dapat diartikan bahwa semakin baik sistem perpajakan maka tingkat penggelapan pajak semakin rendah. Hasil penelitian tersebut sejalan dengan penelitian yang dilakukan Maghfiroh dan Fajarwati (2016) yang menyatakan bahwa hasil pengujian empiris menunjukkan bahwa persepsi wajib pajak mengenai sistem perpajakan berpengaruh negatif terhadap penggelapan pajak. Serta penelitian yang dilakukan oleh Fadhilah (2018), menyatakan bahwa sistem perpajakan berpengaruh negatif terhadap persepsi wajib pajak tentang penggelapan pajak. Dari uraian diatas maka dapat disimpulkan bahwa hipotesis kedua dalam penelitian ini adalah:

H2: Sistem perpajakan berpengaruh negatif terhadap niat seseorang melakukan penggelapan pajak berdasarkan persepsi wajib pajak orang pribadi.

\section{Pengaruh Keadilan Perpjakan terhadap niat seseorang melaukan Penggelapan Pajak}

Menurut Yezzie (2017) dalam penelitiannya menyatakan bahwa salah satu masalah sulit yang sering terjadi dalam pemungutan pajak adalah bagaimana cara mewujudkan atau melaksanaakan keadilan dalam perpajakan, karena keadilan pajak mempunyai perspektif yang luas dimana keadilan antara tiap individu berbedabeda. Anggapan akan pentingnya keadilan pajak bagi seorang wajib pajak dalam pembayaran pajak akan mempengaruhi sikap atau pandangan wajib pajak dalam melakukan kegiatan perpajakannya.

Sistem perpajakan yang tidak adil akan menimbulkan kerugian bagi beberapa orang sehingga akan cenderung mendorong seseorang atau wajib pajak untuk melakukan penggelapan pajak. Sebaliknya jika dengan undang-undang atau peraturan pajak yang adil akan mengurangi wajib pajak yang akan melakukan penggelapan pajak (Pratiwi \& Prabowo, 2019).

Fadhilah (2018) dalam penelitiannya menyatakan bahwa keadilan perpajakan berpengaruh negatif terhadap penggelapan pajak (tax evasion) hal ini berarti bahwa apabila tingkat keadilan yang di lakukan pemerintah semakin tinggi, maka anggapan wajib pajak tentang tindakan penggelapan pajak akan dianggap tidak baik untuk dilakukan. Penelitian tersebut selaras dengan penelitian yang dilakukan oleh Yezzie (2017) yaitu bahwa keadilan perpajakan berpengaruh terhadap persepsi wajib pajak mengenai etika penggelapan pajak/Tax Evasion. Semakin tingggi tingkat keadilan yang dirasakan oleh Wajib Pajak maka persepsi Wajib Pajak mengenai etika penggelapan pajak (Tax Evasion) akan semakin rendah , artinya Wajib Pajak menganggap bahawa tindakan penggelapan pajak adalah perilaku yang tidak etis. Dari uraian diatas maka dapat disimpulkan bahwa hipotesis ketiga dalam penelitian ini adalah:

H3: Keadilan perpajakan berpengaruh negatif terhadap niat seseorang melakukan penggelapan pajak berdasarkan persepsi wajib pajak orang pribadi.

\section{Pengaruh Diskriminasi Perpajakan terhadap niat seseorang melakukan Penggelapan Pajak}

Berdasarkan Undang-Undang No. 39 Tahun 1999 tentang Hak Asasi Manusia Pasal 1 ayat 3, diskriminasi adalah setiap pembatasan, pelecehan atau pengucilan yang langsung maupun tidak langsung yang didasarkan pada pembedaan manusia atas dasar agama, suku, ras, etnik, kelompok, golongan, status sosial, status ekonomi, jenis kelamin, bahasa, keyakinan politik, yang berakibat pengurangan, penyimpangan, atau penghapusan pengakuan, pelaksanaan, atau penggunaan hak asasi manusia dan kebebasan dasar dalam kehidupan baik individual maupun kolektif dalam bidang politik, ekonomi, hukum,sosial, budaya dan aspek kehidupan lainnya. Dapat dikatakan diskriminasi apabila suatu 
kebijakan sudah dibuat dan hanya menguntungkan pihak-pihak teetentu saja.

Tingginya tingkat diskriminasi dalam pelaksanaan perpajakan maka akan semakin meningkatkan persepsi wajib pajak mengenai etika penggelapan pajak. Persepsi wajib pajak terhadap diskriminasi terlihat saat terdapat fasilitas bagi masyarakat yang memiliki NPWP atau tidak memiliki dan pemerintah tidak diperbolehkan melakukan diskriminasi dalam wujud apapun di perpajakan (Faradiza, 2018).

Semakin tinggi tingkat diskriminasi maka akan menyebabkan seseorang atau wajib pajak tidak beretika sehingga penggelapan pajak akan mungkin dilakukan Sebaliknya semakin rendah tingkat diskriminasi maka wajib pajak akan beretika dan penggelapan pajak akan menurun (Basri \& Azhari, 2015).

Menurut Rahman (2013) dalam penelitiannya menyatakan bahwa terdapat pengaruh positif secara parsial antara diskriminasi terhadap penggelapan pajak dilihat berdasarkan nilai signifikan kurang dari 0,05 . Hal ini membuktikan bahwa semakin tingginya diskriminasi maka semakin meningkatnya penggelapan pajak. Hasil penelitian tersebut sejalan dengan hasil penelitian yang dalakukan oleh Suminarsasi dan Supriyadi (2011) bahwa Diskriminasi berpengaruh terhadap persepsi etis wajib pajak. Selain itu menurut nilai koefisiensi regresinya bertanda positif. Jadi apabila tingkat diskriminasi dalam perpajakan semakin tinggi maka perilaku penggelapan pajak cenderung dianggap sebagai perilaku yang etis atau dianggap suatu perpbuatan atau perilaku yang dibenarkan. Dari uraian diatas maka dapat disimpulkan bahwa hipotesis keempat dalam penelitian ini adalah:

H4: Diskriminasi perpajakan berpengaruh positif terhadap niat seseorang melakukan penggelapan pajak berdasarkan persepsi wajib pajak orang pribadi.

\section{Pengaruh Pemahaman Perpajakan terhadap niat seseoorang melakukan Penggelapan Pajak}

Menurut Rahmadi dan Zulaikha (2014) pengaruh pemahaman perpajakan oleh wajib pajak orang pribadi terhadap persepsi atas perilaku penggelapan pajak dapat dikembangkan dengan melihat seberapa besar pemahaman ketentuan perpajakan dapat dipahami oleh wajib pajak dimengerti dan dipatuhi untuk kemudian dilaksanakan. Tujuannya agar dimasa depan, prakatik penggelapan pajak dapat diminimalisir atau dikurangkan serendah mungkin dan wajib pajak dapat memandang perilaku penggelapan pajak tersebut sebagai perilaku yang melanggar hukum dan tidak etis untuk dilakukan.

Seseorang yang memahami perpajakan akan menghindari melakukan penggelapan pajak (Tumewu dan Wahyuni,2018). Seseorang akan dapat melaksanakan sesuatu dengan baik jika tingkat pemahaman perpajakannya baik. Wajib pajak dituntut untuk menguasai peraturan dalam menjalankan kewajiban perpajakannya, serta kewajiban yang dilakukannya agar terhindar dari sanksisanksi yang berlaku (Surahman dan Putra, 2018). Semakin wajib pajak tidak memahami peraturan perpajakan secara jelas maka akan cenderung menjadi wajib pajak yang tidak taat (Agus, Umiyati dan Kurniawan, 2019).

Berdasarkan hasil penelitian yang dilakukan oleh Ardiansyah (2017) bahwa pemahaman perpajakan berpengaruh negatif terhadap tindakan tax evasion. Semakin tinggi pemahaman perpajakan wajib pajak, maka kecenderungan tindakan untuk melakukan tindakan tax evasion oleh wajib pajak akan semakin berkurang. Hal ini sejalan dengan penelitian yang dilakukan oleh Rachmadi (2014) bahwa pemahaman perpajakan yang dimiliki wajib pajak secara parsial berpengaruh signifikan terhadap persepsi wajib pajak atas perilaku penggelapan pajak. Hasil pengujian variabel pemahaman perpajakan menunjukkan adanya indikasi nilai yang negatif. Hal ini mengindikasi bahwa semakin wajib pajak memahami peraturan, tata cara, tentang ketentuan perpajakan ketika melakukan kewajiban perpajakan maka perilaku penggelapan pajak dipandang tidak etis untuk dilakukan. Dari uraian diatas maka dapat disimpulkan bahwa hipotesis kelima dalam penelitian ini adalah: 
H5: Pemahaman perpajakan berpengaruh negatif terhadap niat seseorang melakukan penggelapan pajak berdasarkan persepsi wajib pajak orang pribadi.

\section{Pengaruh Sanksi Perpajakan terhadap niat seseorang melakukan Penggelapan Pajak}

Penegakkan sanksi pajak yang ketat dan berat membuat wajib pajak akan patuh membayar pajak dan tindakan penggelapan pajak dianggap tidak etis atau tidak wajar. Sebaliknya, jika penegakkan sanksi pajak yang tidak ketat dan tidak berat maka wajib pajak akan memilih tidak membayar pajak dan kemungkinan besar akan melakukan perilaku penggelapan pajak yang dianggap sebagai perilaku atau tindakan yang wajar (Maghfiroh dan Fajarwati, 2016).

Berdasarkah hasil penelitian yang dilakukan oleh Sundari (2019) bahwa sanksi perpajakan berpengaruh terhadap persepsi wajib pajak mengenai penggelapan pajak (tax evasion). Hal ini kurang tinginya sanksi pajak yang telah ditetapkan oleh pemerintah menjadikan wajib pajak berani untuk melakukan penggelapan pajak. Selain itu kurangnya sosialisasi tentang sanksi perpajakan yang akan diperoleh jika melakukan penggelapan juga menjadi salah satu faktor yang mengakibatkan wajib pajak melakukan penggelapan pajak. Jadi, semakin tingginya sanksi perpajakan maka semakin rendah penggelapan pajak yang akan dilakukan oleh wajib pajak. Penelitian tersebut diperkuat oleh penelitian yang diakukan oleh Yuliyanti dkk (2017) bahwa sanksi perpajakan berpengaruh terhadap persepsi penggelapan pajak badan. Dari uraian diatas maka dapat disimpulkan bahwa hipotesis keenam dalam penelitian ini adalah:
H6: Sanksi perpajakan berpengaruh negatif terhadap niat seseorang melakukan penggelapan pajak berdasarkan persepsi wajib pajak orang pribadi.

\section{Pengaruh Religusitas terhadap niat seseorang melakukan Penggelapan Pajak}

Perilaku individu dapat dikontrol dengan Agama. Seseorang yang memiliki tingkat religiusitas yang tinggi maka kemungkinan besar akan menghindari bahkan akan menjauhi sikap atau perilaku yang tidak etis karena dengan religiusitas yang tinggi ia akan dapat mengontrol perilakunya. Hal ini juga berlaku pada etika dalam melakukan penggelapan pajak. Keyakinan agama yang kuat yang dimiliki seseorang diharapkan dapat mencegah perilaku ilegal melalui perasaan bersalah terutama dalam hal melakukan penggelapan pajak (Grasmick, Bursik dan Cochran, 1991) dalam (Basri, 2015).

Agama sebagai salah satu penentu perilaku ekonomi dan demogarafi dengan menekankan efek terkait dengan afiliasi keagamaan dan bagaimana hasil positif menjadi individu beragama yang berkaitan dengan kesejahteraan. Hal ini diharapkan dari aturan-aturan moral penegakkan diri yang berbasis disetiap keyakinan individu sebagai manfaat dari agama mereka, tidak hanya untuk diri mereka sendiri tetapi juga untuk seluruh masyarakat (Safitri, 2018).

Berdasarkan penelitian terdahulu yang dilakukan oleh Safitri (2018) menyatakan bahwa religiusitas berpengaruh negatif dan seginifikan terhadap penggelapan pajak. Jika seseorang memiliki religiusitas yang tinggi maka mereka akan cenderung memiliki tingkat kepatuhan perpajakan yang lebih tinggi. Penelitian tersebut didukung oleh penelitian yang dilakukan oleh Surahman dan Putra (2018) yang menyatakan bahwa religiusitas berpengaruh terhadap perspsi 
wajib pajak mengenai etika penggelapan pajak (tax evasion). Hasil ini menjelaskan bahwa jika religiusitas tinggi keyakinan yang kuat pada agama mengurangi sikap untuk melakukan kecurangan pajak. Dari uraian diatas maka dapat disimpulkan bahwa hipotesis ketujuh dalam penelitian ini adalah:

H7: Religiusitas perpajakan berpengaruh negatif terhadap niat seseorang melakukan penggelapan pajak berdasarkan persepsi wajib pajak orang pribadi.

8. Pengaruh Love Of Money, Sistem Perpajakan, Keadilan Perpajakan, Diskriminasi Perpajakan, Pemahaman Perpajakan, Sanksi Perpajakan dan Religiusitas terhadap niat seseorang melakukan Penggelapan Pajak

Hipotesis ini bertujuan untuk menguji secara simultan atau bersamasama variabel love of money, sistem perpajakan, keadilan perpajakan, diskriminasi perpajakan, pemahaman perpajakan, sanksi perpajakan dan religiusitas terhadap penggelapan pajak berdasarkan persepsi wajib pajak orang pribadi. Dengan melakukan analsisis dengan lebih dari dua variabel independen, pengujian dilakukan dengan menggunakan uji simultan. Berdasarkan uraian tersebut maka hipotesis diusulkan sebagai berikut:

H8: Love of money, sistem perpajakan, keadilan perpajakan, diskrminasi perpajakan, pemahaman perpajakan, sanksi perpajakan dan religiusitas berpengaruh terhadap niat seseorang melakukan penggelapan pajak berdasarkan persepsi wajib pajak orang pribadi.

\section{METODOLOGI PENELITIAN}

\section{Metodologi Penelitian}

Penelitian ini termasuk kedalam penelitian kuantitatif, sedangkan jenis data dalam penelitian ini yaitu jenis data primer. Data primer yang diperoleh dalam penelitian ini diperoleh melalui metode survey menggunakan kuesioner yang disebarkan kepada wajib pajak yang terdaftar di Kantor Pelayanan Pajak Pratama Subang yang dapat dijadikan sumber data.

\section{Populasi dan Sampel}

Dalam penelitian ini, yang menjadi populasi adalah seluruh wajib pajak orang pribadi yang melakukan pekerjaan bebas dan terdaftar di Kantor Pelayanan Pajak Pratama Subang. Jumlah sampel dari penelitian ini yaitu 118 wajib pajak orang pribadi yang melakukan pekerjaan bebas yang terdatar di kantor pelayanan pajak pratama subang. Jumlah sampel penelitian ini ditentukan berdasarkan pendapat Sekaran (2006), yang menyatakan bahwa ukuran sampel lebih dari 30 dan kurang dari 500 adalah tepat untuk kebanyakan penelitian

\section{Teknik Pengambilan Sampel}

Dalam penelitian ini teknik pengambilan sampel yang digunakan yaitu nonprobability sampling dengan teknik purposive. Kriteria yang memenuhi untuk dijadikan responden dalam peneitian ini adalah wajib pajak yang melakukan pekerjaan bebas, memiliki NPWP dan terdaftar di KPP Pratama subang.

\section{Definisi Operasional Variabel}

1) Variabel Independen $(X)$

Sugiyono (2017), mendefinisikan variabel dependen sebagai variabel stimulus, prediktor, antecedent. Dalam bahasa Indonesia sering disebut sebagai variabel bebas. Variabel bebas adalah merupakan variabel yang mempengaruhi atau yang menjadi sebab perubahannya atau timbulmya variabel dependen (terikat). Variabel independen dalam penelitian ini yaitu, Love Of Money, sistem perpajakan, keadilan perpajakan, diskriminasi perpajakan, pemahaman perpajakan, sanksi perpajakan dan religiusitas. 
2) Variabel Dependen (Y)

Sugiyono (2017) mendefinisikan variabel dependen sebagai variabel output, kriteria, konsekuen. Dalam bahasa Indonesia sering disebut sebagai variabel terikat. Variabel terikat merupakan variabel yang dipengaruhi atau yang menjadi akibat, karena adanya variabel bebas. Variabel dependen dalam penelitian ini yaitu penggelapan pajak.

\section{Teknik Pengolahan Data}

Penelitian ini menggunakan regresi linear berganda dengan menggunaka program pengolahan data SPSS versi 22.

\section{Uji Kualitas Data \\ Uji Validitas}

Menurut Ghozali (2013) dalam Ardiansyah (2017) uji validitas digunakan untuk mengukur valid tidaknya suatu kuisioner. Kriteria penguian yang digunakan yaitu apabila $r$ hitung $>r$ tabel pada signifikansi $5 \%$, maka butir pertanyaan dinyatakan valid Ghozali (2016) dalam Fadhilah (2017).

\section{Uji Reliabilitas}

Menurut Ghozali (2018) Realibilitas merupakan alat untuk mengukur suatu kuesioner yang merupakan indikator dari variabel atau konstruk. Suatu kuesioner dapat dikatakan reliable atau handal jika jawaban responden terhadap pernyataan yang telah peneliti susun atau buat adalah konsisten atau stabil dari waktu ke waktu.

Menurut Nunnally (1960) dalam Umiyati dan Nurmalasari (2018) suatu kosntruk atau variabel dikatakan reliabel jika memberikan nilai Cronbach's Alpha > 0.60 .

\section{Teknik Analisis Data}

\section{Analisis Data Deskriptif}

Suatu teknik statistik yang digunakan untuk menganalisis data yaitu dengan cara mendeskripsikan atau menggambarkan data yang telah terkumpul sebagaimana adanya tanpa bermaksud untuk membuat kesimpulan yang berlaku umum atau generalisasi sisebut dengan statistik deskriptif
(Sanusi,2013) dalam (Fadhilah, 2018). Menurut Ghozali (2018) Statistik deskriptif memberikan gambaran atau deskripsi suatu data yang dapat dilihat dari nilai ratarata (mean), standar deviasi, varian, maksimum, minimum, sum, range, kurtosis dan skewness (kemencengan distribusi).

\section{Analisis Regresi Linear Berganda}

Analisis regresi digunakan untuk mengetahui hubungan yang ada antara variabel-variabel sehingga dari hubungan yang diperoleh dapat ditaksir variabel yang satu, apabila harga variabel lainnya diketahui (Husein, 2005).

Penelitian ini menggunakan metode regresi linier berganda untuk mengetahui ada tidaknya pengaruh antara variabel (X1) Love Of Money, (X2) Sistem Perpajakan, (X3) Keadilan Perpajakan, (X4) Diskriminasi Perpajakan, (X5) Pemahaman perpajakan, (X6), Sanski Perpajakan dan (X7) Religiusitas terhadap (Y) Penggelapan pajak.

\section{Uji Asumsi Klasik Uji Normalitas}

Uji normalitas bertujuan untuk menguji apakah dalam model regresi, variabel pengganggu atau residual memiliki distribusi normal atau tidak. Model regresi yang baik adalah mempunyai distribusi normal atau mendekati normal (Ghozali, 2013) dalam Andriansyah (2017). Pengujian normalitas dilakukan dengan menggunakan dua metode yaitu histogram dan normal probability plot.

\section{Uji Multikolinearitas}

Uji multikoliniearitas ini digunakan untuk mengetahui ada tidaknya suatu korelasi antar variabel bebas (independen). Artinya variabel independen yang satu dengan yang lain dalam model regresi berganda tidak saling berhubungan secara sempurna. Untuk mengujinya dapat dilihat dari besarnya nilai Tolerance dan VIF (Variance Inflantion Factor) melalui prgram SPSS. Tolerance mengukur variabilitas variabel terpilih yang tidak dijelaskan oleh variabel independen lainnya. Jika VIF kurang dari 
10 dan nilai toleransi lebih dari 0,1 maka regresi bebas dari multikolinearitas.

\section{Uji Heterokedastisitas}

Uji heteroskedastisitas bertujuan untuk menguji apakah dalam model regresi terjadi ketidaksamaan varian dari residual satu pengamatan ke pengamatan lain. Jika variance dari residual satu pengamatan ke pengamatan lain tetap, maka disebut Homokedastisitas dan jika berbeda disebut Heterokedastisitas. Model regresi yang baik adalah yang Homokedaskedastisitas atau tidak terjadi Heterokedastisitas (Ghozali, 2018). Menurut Andriansyah (2017), dalam mendeteksi ada tidaknya heterokedastisitas adalah dengan melihat grafik plot antara nilai prediksi dengan residualnya dan dasar untuk menganalisanya adalah seperti dibawah ini:

1. Heteroskedastisitas diindikasikan telah terjadi jika ada pola tertentu (bergelombang, melebar kemudian menyempit).

2. Heteroskedastisitas tidak terjadi jika tidak ada pola serta titik yang menyebar diatas dan dibawah angka 0 pada sumbu Y.

\section{Uji Hipotesis}

\section{Uji Simultan (F)}

Menurut

Ghozali

(2018)

Mengemukakan uji F (Uji Simultan) digunakan untuk mengetahui seberapa besar variabel independen secara keseluruhan atau bersama-sama berpengaruh signifikan terhadap variabel dependen atau variabel terkait .

Adapun kriteria pengambilan keputusan untuk mneguji hipotesis ini:

1. Jika nilai F-hitung > F-tabel dan nilai signifikansi $<0,05$, maka variabel independen secara simultan atau bersama-sama berpengaruh signifikan terhadap variabel dependen.

2. Jika nilai F-hitung $<$ F-tabel dan nilai signifikansi > 0,05, maka variabel independen secara simultan atau bersama-sama tidak berpengaruh terhadap variabel dependen.
Uji Parsial (T)

Menurut Ghozali (2018) Uji statistik T atau uji parsial digunakan untuk melihat seberapa besar pengaruh variabel independen seacara individual terhadap variabel dependen. Riduwan dan Kuncoro (2008) dalam Sari (2019) mengatakan bahwa jika nilai signifikansi lebih kecil dari 0,05 ( $\mathrm{sig}<0,05$ ), berarti memiliki pengaruh yang signifikan secara individual antara variabel independen dan variabel dependen. Sebaliknya, apabila nilai siginifikasi lebih besar dari 0,05 (sig > $0,05)$, berarti tidak berpengauh signifikan.

\section{Uji Koefisien Determinasi $\left(\mathbf{R}^{2}\right)$}

Agus dkk (2019) mengatakan bahwa uji R2 (uji determinasi) digunakan untuk mengukur seberapa besar kontribusi variabel bebas $(X)$ terhadap variabel terikat (Y). Ketika nilai R2 semakin besar (mendekati satu) menunjukkan semakin baik kemampuan variabel $X$ menerangkan variabel $Y$ dimana $0<R 2<1$. Sebaliknya ketika R2 semakin kecil (mendekati nol) maka akan dapat dikatakan bahwa pengaruh variabel bebas adalah kecil terhadap variabel terikat. Hal ini berarti model yang digunakan tidak kuat untuk menerangkan pengaruh variabel bebas yang diteliti terhadap variabel terikat.

\section{HASIL PENELITIAN DAN PEMBAHASAN}

\section{Hasil Uji Instrumen Penelitian Uji Validitas}

\section{Love Of Money}

Tabel 3

Hasil Validitas Love Of Money Item-Total Statistic

\begin{tabular}{|l|c|c|c|}
\hline $\begin{array}{c}\text { Pernyat } \\
\text { aan }\end{array}$ & $\begin{array}{c}\text { Corrected } \\
\text { Item-Total } \\
\text { Correlation }\end{array}$ & R-tabel & Hasil \\
\hline LOM1 & 0,788 & 0.1809 & Valid \\
\hline LOM2 & 0,875 & 0.1809 & Valid \\
\hline LOM3 & 0,866 & 0.1809 & Valid \\
\hline LOM4 & 0,901 & 0.1809 & Valid \\
\hline LOM5 & 0,898 & 0.1809 & Valid \\
\hline LOM6 & 0,885 & 0.1809 & Valid \\
\hline
\end{tabular}




\begin{tabular}{|c|c|c|c|}
\hline $\begin{array}{c}\text { Pernyat } \\
\text { aan }\end{array}$ & $\begin{array}{c}\text { Corrected } \\
\text { Item-Total } \\
\text { Correlation }\end{array}$ & R-tabel & Hasil \\
\hline LOM7 & 0,899 & 0.1809 & Valid \\
\hline LOM8 & 0,853 & 0.1809 & Valid \\
\hline
\end{tabular}

Sumber: Hasil pengolahan data dengan

SPSS versi 22

Hasil dari pengujian telah menunjukkan bahwa pernyataanpernyataan yang terdapat pada variabel love of money dinyatakan valid, karena nilai $r$ hitung lebih besar dari $r$ tabel, maka item-item tersebut dapat digunakan dalam model regresi

\section{Sistem Perpajakan \\ Tabel 4}

Hasil Sistem Perpajakan Item-Total Statistic

\begin{tabular}{|c|c|c|c|}
\hline Pernyataan & $\begin{array}{c}\text { Corrected } \\
\text { Item-Total } \\
\text { Correlation }\end{array}$ & R-tabel & Hasil \\
\hline SP1 & 0,764 & 0.1809 & Valid \\
\hline SP2 & 0,697 & 0.1809 & Valid \\
\hline SP3 & 0,733 & 0.1809 & Valid \\
\hline SP4 & 0,749 & 0.1809 & Valid \\
\hline
\end{tabular}

Sumber: Hasil pengolahan data dengan

SPSS versi 22

Hasil dari pengujian telah menunjukkan bahwa pernyataanpernyatan yang terdapat pada variabel sistem perpajakan dinyatakan valid, karena nilai $r$ hitung lebih besar dari $r$ tabel, maka item-item tersebut dapat digunakan dalam model regresi.

\section{Keadilan Perpajakan \\ Tabel 5}

Hasil Keadilan Perpajakan Item-Total Statistic

\begin{tabular}{|c|c|c|c|}
\hline Pernyataan & $\begin{array}{c}\text { Corrected } \\
\text { Item-Total } \\
\text { Correlation }\end{array}$ & R-tabel & Hasil \\
\hline KP1 & 0,646 & 0.1809 & Valid \\
\hline KP2 & 0,767 & 0.1809 & Valid \\
\hline KP3 & 0,715 & 0.1809 & Valid \\
\hline KP4 & 0,713 & 0.1809 & Valid \\
\hline KP5 & 0,773 & 0.1809 & Valid \\
\hline KP6 & 0,837 & 0.1809 & Valid \\
\hline
\end{tabular}

\begin{tabular}{|c|c|c|c|}
\hline Pernyataan & $\begin{array}{c}\text { Corrected } \\
\text { Item-Total } \\
\text { Correlation }\end{array}$ & R-tabel & Hasil \\
\hline KP7 & 0,762 & 0.1809 & Valid \\
\hline KP8 & 0,732 & 0.1809 & Valid \\
\hline KP9 & 0,738 & 0.1809 & Valid \\
\hline KP10 & 0,665 & 0.1809 & Valid \\
\hline KP11 & 0,651 & 0.1809 & Valid \\
\hline
\end{tabular}

Sumber: Hasil pengolahan data dengan SPSS versi 22

Hasil dari pengujian telah menunjukkan bahwa pernyataanpernyatan yang terdapat pada variabel sistem perpajakan dinyatakan valid, karena nilai r hitung lebih besar dari r tabel, maka item-item tersebut dapat digunakan dalam model regresi.

\section{Diskriminasi Perpajakan Tabel 6 \\ Hasil Diskriminasi Perpajakan Item-Total Statistic}

\begin{tabular}{|c|c|c|c|}
\hline Pernyataan & $\begin{array}{c}\text { Corrected } \\
\text { Item-Total } \\
\text { Correlation }\end{array}$ & R-tabel & Hasil \\
\hline DP1 & 0,818 & 0.1809 & Valid \\
\hline DP2 & 0,817 & 0.1809 & Valid \\
\hline DP3 & 0,828 & 0.1809 & Valid \\
\hline DP4 & 0,863 & 0.1809 & Valid \\
\hline
\end{tabular}

Sumber: Hasil pengolahan data dengan SPSS versi 22

Hasil dari pengujian telah menunjukkan bahwa pernyataanpernyatan yang terdapat pada variabel diskriminasi perpajakan dinyatakan valid, karena nilai r hitung lebih besar dari $r$ tabel, maka item-item tersebut dapat digunakan dalam model regresi.

\section{Pemahaman Perpajakan Tabel 7}

Hasil Pemahaman Perpajakan Item-Total Statistic

\begin{tabular}{|c|c|c|c|}
\hline Pernyataan & $\begin{array}{c}\text { Corrected } \\
\text { Item-Total } \\
\text { Correlation }\end{array}$ & R-tabel & Hasil \\
\hline PP1 & 0,785 & 0.1809 & Valid \\
\hline PP2 & 0,770 & 0.1809 & Valid \\
\hline PP3 & 0,785 & 0.1809 & Valid \\
\hline
\end{tabular}




\begin{tabular}{|c|c|c|c|}
\hline Pernyataan & $\begin{array}{c}\text { Corrected } \\
\text { Item-Total } \\
\text { Correlation }\end{array}$ & R-tabel & Hasil \\
\hline PP4 & 0,833 & 0.1809 & Valid \\
\hline PP5 & 0,738 & 0.1809 & Valid \\
\hline
\end{tabular}

Sumber: Hasil pengolahan data dengan SPSS versi 22

Hasil dari pengujian telah menunjukkan bahwa pernyataanpernyatan yang terdapat pada variabel pemahaman perpajakan dinyatakan valid, karena nilai $r$ hitung lebih besar dari $r$ tabel, maka item-item tersebut dapat digunakan dalam model regresi.

\section{Sanksi Perpajakan \\ Tabel 8}

Hasil Sanksi Perpajakan Item-Total Statistic

\begin{tabular}{|c|c|c|c|}
\hline Pernyataan & $\begin{array}{c}\text { Corrected } \\
\text { Item-Total } \\
\text { Correlation }\end{array}$ & R-tabel & Hasil \\
\hline SP1 & 0,695 & 0.1809 & Valid \\
\hline SP2 & 0,816 & 0.1809 & Valid \\
\hline SP3 & 0,796 & 0.1809 & Valid \\
\hline
\end{tabular}

Sumber: Hasil pengolahan data dengan SPSS versi 22

Hasil dari pengujian telah menunjukkan bahwa pernyataanpernyatan yang terdapat pada variabel sanksi perpajakan dinyatakan valid, karena nilai $r$ hitung lebih besar dari $r$ tabel, maka item-item tersebut dapat digunakan dalam model regresi.

\section{Religiusitas}

\section{Tabel 9}

Hasil Religiusitas

Item-Total Statistic

\begin{tabular}{|c|c|c|c|}
\hline Pernyataan & $\begin{array}{c}\text { Corrected } \\
\text { Item-Total } \\
\text { Correlation }\end{array}$ & R-tabel & Hasil \\
\hline R1 & 0,734 & 0.1809 & Valid \\
\hline R2 & 0,724 & 0.1809 & Valid \\
\hline R3 & 0,811 & 0.1809 & Valid \\
\hline R4 & 0,825 & 0.1809 & Valid \\
\hline R5 & 0,785 & 0.1809 & Valid \\
\hline
\end{tabular}

Sumber: Hasil pengolahan data dengan

SPSS versi 22
Hasil dari pengujian telah menunjukkan bahwa pernyataanpernyatan yang terdapat pada variabel religiusitas dinyatakan valid, karena nilai $r$ hitung lebih besar dari $r$ tabel, maka itemitem tersebut dapat digunakan dalam model regresi.

\section{Penggelapan Pajak Tabel 10 Hasil Penggelapan Pajak Item-Total Statistic}

\begin{tabular}{|c|c|c|c|}
\hline Pernyataan & $\begin{array}{c}\text { Corrected } \\
\text { Item-Total } \\
\text { Correlation }\end{array}$ & R-tabel & Hasil \\
\hline PPj1 & 0,517 & 0.1809 & Valid \\
\hline PPj2 & 0,539 & 0.1809 & Valid \\
\hline PPj3 & 0,526 & 0.1809 & Valid \\
\hline PPj4 & 0,505 & 0.1809 & Valid \\
\hline PPj5 & 0,708 & 0.1809 & Valid \\
\hline PPj6 & 0,692 & 0.1809 & Valid \\
\hline PPj7 & 0,602 & 0.1809 & Valid \\
\hline PPj8 & 0,539 & 0.1809 & Valid0 \\
\hline
\end{tabular}

Sumber: Hasil pengolahan data dengan SPSS versi 22

Hasil dari pengujian telah menunjukkan bahwa pernyataanpernyatan yang terdapat pada variabel penggelapan pajak dinyatakan valid, karena nilai $r$ hitung lebih besar dari $r$ tabel, maka item-item tersebut dapat digunakan dalam model regresi.

\section{Uji Reliabilitas}

\section{Tabel 11}

Hasil Uji Reliabilitas

\begin{tabular}{|l|c|c|c|}
\hline Variabel Penelitian & $\begin{array}{c}\text { Cronbach's Alpha } \\
\text { Based On } \\
\text { Standardized }\end{array}$ & $\begin{array}{c}\text { Batas Cronbach's } \\
\text { Alpha }\end{array}$ & Hasil \\
\hline Love Of Money & 0,967 & 0,60 & Reliabel \\
\hline Sistem Perpajakan & 0,877 & 0,60 & Reliabel \\
\hline Keadilan Perpajakan & 0,935 & 0,60 & Reliabel \\
\hline Diskriminasi & 0,928 & 0,60 & Reliabel \\
\hline Pemahaman Perpajakan & 0,915 & 0,60 & Reliabel \\
\hline Sanksi Perpajakan & 0,880 & 0,60 & Reliabel \\
\hline Religiusitas & 0,912 & 0,60 & Reliabel \\
\hline Penggelapan Pajak & 0,845 & 0,60 & Reliabel \\
\hline
\end{tabular}

Sumber: Hasil pengolahan data dengan SPSS versi 22

Uji Reliabilitas dapat dilihat dari nilai Cronbach Alpha (a), dimana jika suatu variabel dapat dinyatakan reliabel apabila 
nilai Cronbach Alpha $(\alpha)>0,60$. Hasill pengujian menunjukkan bahwa semua variabel dinyatakan reliabel.

\section{Uji Asumsi Klasik Uji Normalitas}

Berdasarkan grafik di bawah maka dapat disimpulkan bahwa data bersifat normal, karena grafik diatas menggambarkan pola yang berbentuk lonceng.

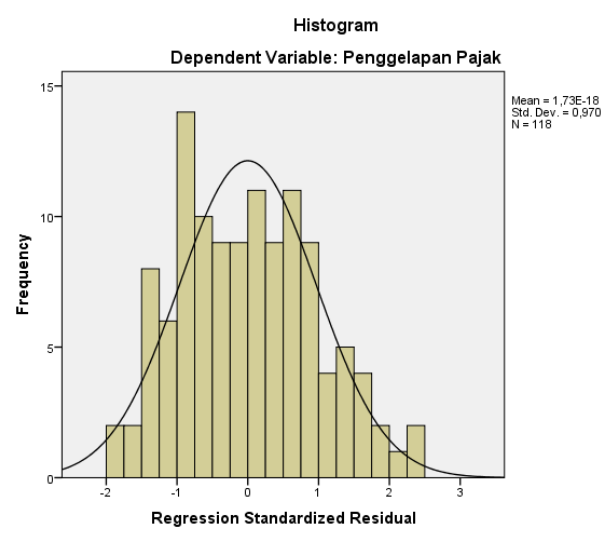

Gambar 2

Histogram Normalitas

Sumber: Hasil pengolahan data dengan SPSS versi 22

Pada gambar Normal P-P Plot of Regression Standardized Residual di bawah ini dapat dilihat bahwa titik-titik menyebar disekitar garis diagonal dan cenderung mengikuti arah garis diagonal. Maka hal ini dapat disimpulkan bahwa data dalam penelitian ini memenuhi asumsi normalitas atas data berdistribusi normal.

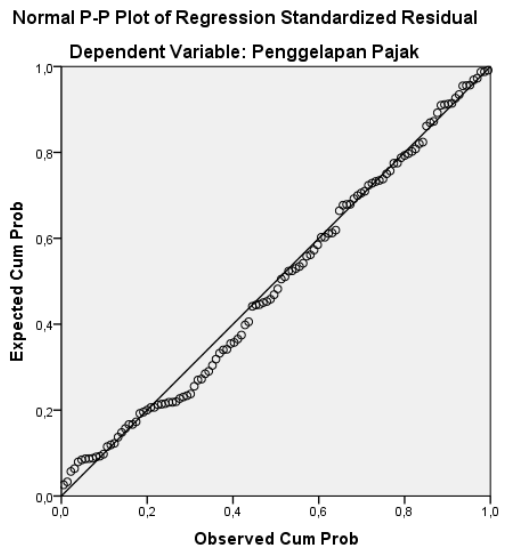

Gambar 3

Uji Normalitas dengan Normal

Probability Plot

Sumber: Hasil pengolahan data dengan SPSS versi 22

\section{Uji Multikolinearitas}

\section{Tabel 12}

Hasil Uji Multikolinearitas

\begin{tabular}{|l|c|c|c|}
\hline \multicolumn{1}{|c|}{ Model } & \multicolumn{2}{|c|}{ Colinearity Statistic } & \multirow{2}{*}{ Hasil } \\
\cline { 2 - 3 } & Tolerance & VIF & \\
\hline (Constant) & & & \\
\hline Love Of Money & 0,962 & 1,040 & Tidak Terjadi Multikolinearitas \\
\hline Sistem Perpajakan & 0,494 & 2,024 & Tidak Terjadi Multikolinearitas \\
\hline Keadilan Perpajakan & 0,418 & 2,391 & Tidak Terjadi Multikolinearitas \\
\hline Diskriminasi & 0,700 & 1,429 & Tidak Terjadi Multikolinearitas \\
\hline Pemahaman Perpajakan & 0,474 & 2,111 & Tidak Terjadi Multikolinearitas \\
\hline Sanksi Perpajakan & 0,558 & 1,794 & Tidak Terjadi Multikolinearitas \\
\hline Religiusitas & 0,702 & 1,424 & Tidak Terjadi Multikolinearitas \\
\hline
\end{tabular}

Sumber: Hasil pengolahan data dengan SPSS versi 22

Berdasarkan tabel diatas hasil pengujian multikolinearitas pada semua variabel, menunjukan bahwa semua variabel tidak terjadi multikolinearitas karena nilai tolerance dari semua variabel lebih dari $0,1(>0,1)$ dan nilai VIF nya pun kurang dari $10 \quad(<10)$ untuk semua variabel. Sehingga dapat disimpulkan bahwa hasil uji ini tidak terjadi multikolinearitas.

\section{Uji Heterokedastisitas}

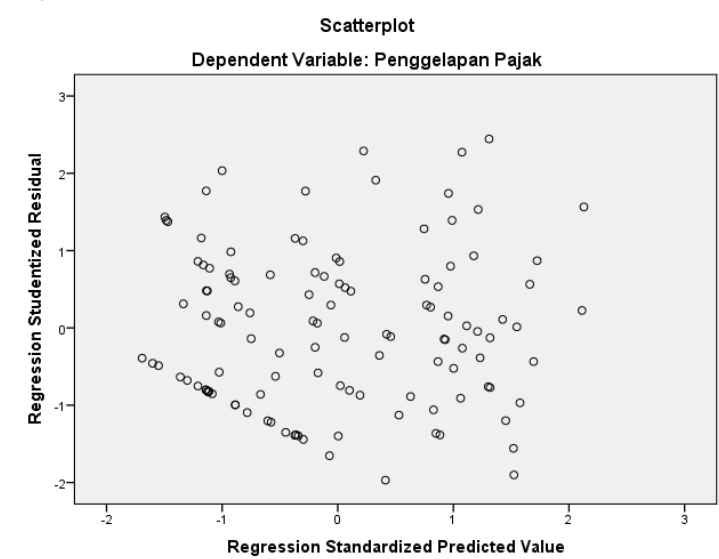

Gambar 4

Uji Heterokedastisitas

Sumber: Hasil pengolahan data dengan SPSS versi 22

Hasil dari uji heterokedastisitas dalam penelitian ini menunjukan bahwa 
seluruh variabel yang terdapat dalam penelitian ini bebas dari masalah heterokedastisitas karena semua indikator angket menyebar secara acak atau tidak membentuk pola tertentu.

\section{Analisis Regresi Linear Berganda Tabel 13 Hasil Analisis Regresi Linear}

\begin{tabular}{|l|c|c|c|c|c|}
\hline \multirow{2}{*}{ Model } & \multicolumn{2}{|c|}{$\begin{array}{c}\text { Unstandardized } \\
\text { Coefficients }\end{array}$} & $\begin{array}{c}\text { Standardized } \\
\text { Coefficients }\end{array}$ & \multirow{2}{*}{ t } & \multirow{2}{*}{ Sig. } \\
\cline { 2 - 5 } & B & $\begin{array}{c}\text { Std. } \\
\text { Error }\end{array}$ & Beta & & \\
\hline 1 (Constant) & 37,138 & 3,451 & & 10,763 & 0,000 \\
\hline Love Of Money & $-0,007$ & 0,039 & $-0,014$ & $-0,176$ & 0,861 \\
\hline Sistem Perpajakan & 0,324 & 0,171 & 0,204 & 1,897 & 0,061 \\
\hline Keadilan Perpajakan & $-0,145$ & 0,082 & $-0,208$ & $-1,779$ & 0,078 \\
\hline Diskriminasi Perpajakan & 0,173 & 0,108 & 0,145 & 1,603 & 0,112 \\
\hline Pemahaman Perpajakan & $-0,366$ & 0,138 & $-0,291$ & $-2,659$ & 0,009 \\
\hline Sanksi Perpajakan & $-0,172$ & 0,229 & $-0,076$ & $-0,752$ & 0,454 \\
\hline Religiusitas & $-0,669$ & 0,160 & $-0,376$ & $-4,181$ & 0,000 \\
\hline
\end{tabular}

Sumber: Hasil pengolahan data dengan SPSS versi 22

$$
\begin{gathered}
Y=37,183-0,007 X_{1}+0,324 X_{2}-0,145 \\
X_{3}+0,173 X_{4}-0,366 X_{5}-0,172 X_{6}-0,669 \\
X_{7}
\end{gathered}
$$

Dari persamaan regresi berganda diatas maka persamaan tersebut memiliki makna sebagai berikut:

1. Nilai konstanta $(\alpha)$ sebesar 37,183 dapat diartikan bahaw apabila nilai Love Of Money (X1), Sistem Perpajakan (X2), Keadilan Perpajakan (X3), Diskriminasi Perpajakan (X4), Pemahaman perpajakan (X5), Sanski Perpajakan (X6) Religiusitas $(X 7)=0$ (nol) atau dianggap konstan, maka nilai Penggelapan Pajak $(Y)=37,183$.

2. Koefisien regresi Love of Money (X1) sebesar $(-0,007)$, diartikan bahwa apabila variabel Love of Money mengalami kenaikan (satu) satuan, sedangkan variabel independen lainnya dianggap konstan, maka variabel dependen yaitu variabel penggelapan pajak akan mengalami penurunan sebesar 0,007.

3. Koefisien regresi sistem perpajakan (X2) sebesar 0,324, diartikan bahwa apabila variabel sistem perpajakan mengalami peningkatan (satu) satuan, sedangkan variabel independen lainnya dianggap konstan, maka variabel dependen yaitu penggelapan pajak juga akan mengalami kenaikan sebesar 0,034.

4. Koefisien regresi keadilan perpajakan (X3) sebesar $(-0,145)$, diartikan bahwa apabila keadilan perpajakan mengalami kenaikan setiap (satu) satuan, sedangakn variabel independen lainnya dianggap konstan, maka variabel dependen yaitu penggelapan pajak akan mengalami penurunan sebesar 0,145 .

5. Koefisisen regresi diskriminasi perpajakan (X4) sebesar 0,173, diartikan bahwa apabila diskriminasi perpajakan mengalami peningkatan (satu) satuan, sedangkan variabel independen lainnya dianggap konstan, maka variabel dependen yaitu penggelapan pajak akan mengalami peningkatan sebesar 0,173 .

6. Koefisien regresi pemahaman perpajakan (X5) sebesar $(-0,366)$, diartikan bahwa apabila pemahaman perpajakan mengalami kenaikan (satu) satuan sedangkan variabel independen lainnya dianggap konstan, maka variabel dependen yaitu penggelapan pajak akan mengalami penurunan sebesar 0,366.

7. Koefisien regresi sanksi perpajakan (X6) sebesar $(-0,172)$, diartikan bahwa apabila sanksi perpajakan mengalami kenaikan (satu) satuan, sedangkan variabel independen lainnya dianggap konstan, maka variabel dependen yaitu penggelapan pajak akan mengalami penurunan sebesar 0,172 .

8. Koefisien regresi religiusitas (X7) sebesar $(-0,669)$, diartikan bahwa apabila religiusitas mengalami kenaikan sebesar (satu) satuan, sedangkan variabe independen lainnya dianggap konstan, maka variabel dependen yaitu penggelapan pajak akan mengalami penurunan sebesar 0,699. 


\section{Uji Hipotesis Uji Simultan (F)}

Tabel 14

Hasil Uji Simultan (Uji F)

\begin{tabular}{|l|l|r|r|r|r|r|}
\hline \multicolumn{2}{|c|}{ Model } & $\begin{array}{c}\text { Sum of } \\
\text { Squares }\end{array}$ & \multicolumn{1}{|c|}{ Df } & $\begin{array}{c}\text { Mean } \\
\text { Square }\end{array}$ & F & Sig. \\
\hline \multirow{3}{*}{1} & Regression & 675,575 & 7 & 96,511 & 9,380 & $0,000^{6}$ \\
\cline { 2 - 7 } & Residual & 1131,781 & 110 & 10,289 & & \\
\cline { 2 - 7 } & Total & 1807,356 & 117 & & & \\
\hline
\end{tabular}

Sumber: Hasil pengolahan data dengan SPSS versi 22

Berdasarkan hasil pengujian pada tabel diatas, menunjukan nilai signifikansi sebesar 0,000 dimana nilai signifikansi tersebut kurang dari $0,05(0,000<0,000)$. Selain itu dapat dilihat dari hasil perbandingan antara $f_{\text {hitung }}$ dan $f_{\text {tabel }}$ yang menunjukan bahwa nilai $f_{\text {hitung }}$ sebesar 9,380 sedangkan $f_{\text {tabel }}$ sebesar 2,18. Dari hasil tersebut dapat dilihat bahwa $f_{\text {hitung }}>$ $f_{\text {tabel }}$ yaitu $9,380>2,18$ maka dapat disimpulkan $\mathrm{H} 8$ diterima. Artinya bahwa seluruh variabel independen (Love Of Money, Sistem Perpajakan, Keadilan Perpajakan, Diskriminasi Perpajakan, Pemahaman perpajakan, Sanski Perpajakan dan Religiusitas) secara bersama-sama atau secara simultan berpengaruh terhadap variabel dependen yaitu penggelapan pajak.

\section{Uji Parsial (T)}

\section{Tabel 15}

Hasil Uji Parsial (Uji T)

\begin{tabular}{|l|c|c|c|c|c|}
\hline \multirow{1}{*}{ Model } & \multicolumn{2}{|c|}{$\begin{array}{c}\text { Unstandardized } \\
\text { Coefficients }\end{array}$} & $\begin{array}{c}\text { Standardized } \\
\text { Coefficients }\end{array}$ & \multirow{2}{*}{ t } & \multirow{2}{*}{ Sig. } \\
\cline { 2 - 5 } & B & $\begin{array}{c}\text { Std. } \\
\text { Error }\end{array}$ & Beta & & \\
\hline 1 (Constant) & 37,138 & 3,451 & & 10,763 & 0,000 \\
\hline Love Of Money & $-0,007$ & 0,039 & $-0,014$ & $-0,176$ & 0,861 \\
\hline Sistem Perpajakan & 0,324 & 0,171 & 0,204 & 1,897 & 0,061 \\
\hline Keadilan Perpajakan & $-0,145$ & 0,082 & $-0,208$ & $-1,779$ & 0,078 \\
\hline Diskriminasi Perpajakan & 0,173 & 0,108 & 0,145 & 1,603 & 0,112 \\
\hline Pemahaman Perpajakan & $-0,366$ & 0,138 & $-0,291$ & $-2,659$ & 0,009 \\
\hline Sanksi Perpajakan & $-0,172$ & 0,229 & $-0,076$ & $-0,752$ & 0,454 \\
\hline Religiusitas & $-0,669$ & 0,160 & $-0,376$ & $-4,181$ & 0,000 \\
\hline
\end{tabular}

Sumber: Hasil pengolahan data dengan SPSS versi 22

Berdasarkan tabel diatas dapat disimpulkan bahwa:

a. Love of Money (X1)

Berdasarkan hasil uji $t$ (parsial), variabel love of money $\left(\mathrm{X}_{1}\right)$ memiliki nilai siginifikansi sebesar 0,861 lebih besar dari 0,05 $(0,861>0,05)$ artinya bahwa variabel Love Of Money tidak berpengaruh terhadap variabel penggelapan pajak. Dengan demikian maka hipotesis pertama $(\mathrm{H} 1)$ ditolak karena variabel Love Of Money tidak berpengaruh terhadap penggelapan pajak.

b. Sistem Perpajakan (X2)

Berdasarkan hasil uji $t$ (parsial), variabel sistem perpajakan $\left(X_{2}\right)$ memiliki nilai signifikasi sebesar 0,061 lebih besar dari 0,05 $(0,061>0,05)$ artinya bahwa variabel sistem perpajakan tidak berpengaruh terhadap penggelapan pajak. Dengan demikian maka hipotesis kedua $(\mathrm{H} 2)$ ditolak karena variabel sistem perpajakan tidak berpengaruh terhadap penggelapan pajak.

c. Keadilan Perpajakan (X3)

Berdasarkan hasil uji $t$ (parsial), variabel keadilan perpajakan $\left(X_{3}\right)$ memiliki nilai signifikansi sebesar 0,078 lebih besar dari 0,05 $(0,078>$ $0,05)$ artinya bahwa variabel keadilan perpajakan tidak berpengaruh terhadap penggelapan pajak. Dengan demikian maka hipotesis ketiga ditolak karena variabel keadilan perpajakan tidak berpengaruh terhadap penggelapan pajak.

d. Diskriminasi Perpajakan (X4)

Berdasarkan hasil uji $t$ (parsial), variabel diskriminasi perpajakan $\left(\mathrm{X}_{4}\right)$ memiliki nilai siginifikansi sebesar 0,112 lebih besar dari $0,05(0,112>$ $0,05)$ artinya bahwa variabel diskriminasi perpajakan tidak berpengaruh terhadap penggelapan pajak. Dengan demikian maka hipotesis keempat $(\mathrm{H} 4)$ ditolak karena variabel diskriminasi tidak berpengaruh terhadap penggelapan pajak.

e. Pemahaman Perpajakan (X5)

Berdasarkan hasil uji $t$ (parsial), variabel pemahaman perpajakan $\left(X_{5}\right)$ memiliki nilai siginfikansi sebesar 0,009 lebih kecil dari 0,05 $(0,009<$ $0,05)$ dan nilai koefisien regresi sebesar -0,366 (bertada negatif), artinya bahwa variabel pemahaman perpajakan berpengaruh negatif 
terhadap penggelapan pajak. Dengan demikian maka hipotesis kelima (H5) diterima karena variabel pemahaman perpajakan berpengaruh negatif terhadap penggelapan pajak.

f. Sanksi Perpajakan (X6)

Berdasarkan hasil uji $t$ (parsial), variabel sanksi perpajakan $\left(X_{6}\right)$ memiliki nilai signifikansi sebesar 0,454 lebih besar dari $0,05(0,454>$ 0,05 ) artinya bahwa variabel sanksi perpajakan tidak berpengaruh terhadap penggelapan pajak. Dengan demikian maka hipotesis keenam $(\mathrm{H} 6)$ ditolak karena sanksi perpajakan tidak berpengaruh terhadap penggelapan pajak.

g. Religiusitas (X7)

Berdasarkan hasil uji $t$ (parsial), variabel religiusitas $\left(X_{7}\right)$ memiliki nilai signifikansi sebesar 0,000 lebih kecil dari $0,05(0,000<0,05)$ dan nilai koefisien regresi sebesar $-0,669$ (bertanda negatif), artinya bahwa variabel religiusitas berpengaruh negatif terhadap penggelapan pajak. Dengan demikian maka hipotesis ketujuh $(\mathrm{H} 7)$ diterima karena variabel religiusitas berpengaruh negatif terhadap penggelapan pajak.

\section{Koefisien Determinasi}

Tabel 16

Koefisien Determinasi $\left(\mathbf{R}^{2}\right)$

\begin{tabular}{|c|c|c|c|c|}
\hline Model & $\mathbf{R}$ & $\mathbf{R}$ Square & $\begin{array}{c}\text { Adjusted } \mathbf{R} \\
\text { Square }\end{array}$ & $\begin{array}{c}\text { Std. Error of the } \\
\text { Estimate }\end{array}$ \\
\hline 1 & $0,611^{2}$ & 0,374 & 0,334 & 3,208 \\
\hline
\end{tabular}

Sumber: Hasil pengolahan data dengan SPSS versi 22

Berdasarkan hasil pengujian koefisien determinasi pada tabel diatas, menunjukan bahwa nilai Adjusted $R$ Square adalah sebesar 0,374 berarti $37,4 \%$ variabel penggelapan pajak dapat dijelaskan oleh Love Of Money (X1), Sistem Perpajakan (X2), Keadilan Perpajakan (X3), Diskriminasi Perpajakan (X4), Pemahaman perpajakan (X5), Sanski Perpajakan (X6) dan Religiusitas (X7) sedangan sisanya sebesar $62,6 \%$ dijelaskan oleh variabel lain yang tidak diteliti dalam penelitian ini.

\section{Pembahasan}

\section{Pengaruh Love Of Money terhadap Penggelapan Pajak}

Dalam penelitian ini hasil analisis data yang telah dilakukan menunjukan bahwa tidak adanya pengaruh variabel Love Of Money terhadap penggelapan pajak. Hal ini dikarenakan hasil nilai signifikansi lebih besar dari nilai $(\alpha)(0,861$ $>0,05)$. Dengan demikian maka $\mathrm{H} 1$ ditolak karena love of money tidak berpengaruh terhadap penggelapan pajak.

Hasil penelitian ini belum berhasil menemukan adanya pengaruh atau hubungan love of money terhadap penggelapan pajak. Berdasarkan data yang diperoleh dari responden, yaitu wajib pajak pekerja bebas yang terdaftar di KPP Pratama Subang hasil menunjukan bahwa love of money tidak memiliki pengaruh terhadap wajib pajak. Artinya bahwa tinggi dan rendahnya love of money seorang wajib pajak, tidak akan mempengaruhi tingkat penggelapan pajak. Hal ini dapat dijelaskan bahwa sikap love of money atau kecintaan seseorang terhadap uang tidak memandang kondisi untuk wajib pajak melakukan penggelapan pajak. Tidak adanya pengaruh ini dapat disebabkan bahwa terdapat faktor lain yang dapat mempengaruhi persepsi seseorang, yaitu kontrol perilaku yang dimiliki setiap individu. Kontrol keprilakuan merupakan sejumlah kontrol yang diyakini dapat mendorong wajib pajak dalam menampilkan perilaku kepatuhan terhadap pajak.

Penelitian ini sejalan dengan penelitian yang dilakukan oleh Surahman dan Putra (2018) yang menyatakan bahwa love of money tidak berpengaruh terhadap persepsi wajib pajak mengenai etika penggelapan pajak (tax evasion). Hal ini diperkuat oleh penelitian yang dilakukan oleh Sofha dan Machmuddah (2019) yang menyatakan bahwa love of money tidak berpengaruh terhadap persepsi etika penggelapan pajak.

Namun penelitian ini tidak sejalan dengan dengan penelitian yang dilakukan oleh Asih dan Dwiyanti (2019) yang 
menyatakan bahwa love of money berpengaruh negatif terhadap persepsi etika penggelapan pajak pada wajib pajak orang pribadi. Semakin tinggi sifat love of money yang dimiliki oleh wajib pajak, maka persepsi wajib pajak atas etika penggelapan pajak juga akan semakin tinggi , dimana wajib pajak akan cenderung melakukan penggelapan pajak.

\section{Pengaruh Sistem Perpajakan terhadap Penggelapan Pajak}

Dalam penelitian ini hasil analisis data yang telah dilakukan menunjukan bahwa nilai signifikasi sebesar 0,061 lebih besar dari $0,05(0,061>0,05)$ artinya bahwa variabel sistem perpajakan tidak berpengaruh terhadap penggelapan pajak. Hal ini mengindikasikan bahwa baik atau buruknya sistem perpajakan tidak akan mempengaruhi seseorang untuk melakukan penggelapan pajak.

Sistem pajak yang digunakan di Indonesia yaitu self assessment system. Self assessment system ini mengharuskan wajib pajak berperan aktif dalam kegiatan perpajakannya. Hasil penelitian menunjukan bahwa sistem perpajakan tidak memiliki pengaruh terhadap penggelapan. Artinya baik dan buruknya sistem perpajakan yang berlaku saat ini tidak akan mempengaruhi wajib pajak untuk melakukan tindakan penggelapan pajak. Hal tersebut dapat terjadi karena adanya faktor lain yang dapat mendorong wajib pajak dalam melakukan penggelapan pajak, seperti adanya kepentingan diri sendiri dan peluang atau kesempatan untuk melakukan tindakan penggelapan pajak.

Hasil penelitian ini sejalan dengan penelitian yang dilakukan oleh Tumewu dan Wahyuni (2018), yang menyatakan bahwa sistem perpajakan tidak berpengaruh terhadap persepsi mahasiswa tentang penggelapan pajak. Hal ini juga didukung oleh penelitian yang dilakukan oleh Agus, Umiyati dan Kurniawan (2019) menyatakan bahwa sistem perpajakan tidak berpengaruh terhadap penggelapan pajak. Dan diperkuat oleh Sundari (2019) yang menyatakan bahwa Self Assessment System tidak berpengaruh terhadap persepsi wajib pajak mengenai penggelapan pajak.

Namun hasil penelitian tersebut tidak sejalan dengan penelitian yang dilakukan oleh Reswina dan Zulvia (2018) yang menyatakan bahwa sistem perpajakan berpengaruh terhadap persepsi wajib pajak.

\section{Pengaruh Keadilan Perpajakan terhadap Penggelapan Pajak}

Dalam penelitian ini hasil analisis data yang telah dilakukan menunjukan bahwa nilai signifikansi sebesar 0,078 lebih besar dari 0,05 (0,078>0,05) artinya bahwa variabel keadilan perpajakan tidak berpengaruh terhadap penggelapan pajak. Hal ini mengindikasikan bahwa semakin tinggi dan rendahnya tingkat keadilan perpajakan tidak akan berpengaruh terhadap peningkatan atau penurunan penggelapan pajak.

Penelitian ini belum berhasil menemukan pengaruh keadilan perpajakan terhadap penggelapan pajak. Pajak dipandang adil jika pajak yang dibebankan sebanding dengan kemampuan membayar dan manfaat yang diterima atau dirasakan. Adanya pemikiran tentang pentingnya keadilan perpajakan bagi seseorang termasuk dalam pembayaram pajak juga tidak akan mempengaruhi sikap wajib pajak dalam membayar pajak. Hal ini dapat terjadi karena setiap individu memiliki persepsi yang berbeda dan luas terhadap keadilan yang dirasakan atau diterima. Seseorang seringkali mengartikan bahwa keadilan harus diberikan dengan jumlah yang sama banyak atau merata, namun tidak sedikit juga yang mengartikan bahwa keadilan harus diberikan berdasarkan apa yang dibutuhkan.

Hasil penelitian ini sejalan dengan penelitian yang dilakukan oleh Tumewu dan Wahyuni (2018) menyatakan bahwa variabel keadilan dalam perpajakan tidak berpengaruh kepada persepsi mahasiswa terhadap penggelapan pajak. Hal ini diperkuat dengan penelitian yang dilakukan oleh Fhyel (2018) yang menyatakan bahwa keadilan perpajakan 
tidak berpengaruh terhadap penggelapan pajak.

Namun hasil penelitian ini tidak sejalan dengan penelitian yang dilakukan oleh Pratiwi dan Prabowo (2019) menyatakan bahwa keadilan pajak memilki pengaruh terhadap persepsi wajib pajak orang pribadi mengenai penggelapan pajak.

\section{Pengaruh Diskriminasi Perpajakan terhadap Penggelapan Pajak}

Dalam penelitian ini hasil data menunjukan bahwa nilai siginifikansi sebesar 0,112 lebih besar dari $0,05(0,112$ $>0,05)$ artinya bahwa variabel diskriminasi perpajakan tidak berpengaruh terhadap penggelapan pajak. hal ini mengindikasikan bahwa tinggi rendahnya diskriminasi tidak akan mempengaruhi seseorang dalam melakukan penggelapan pajak.

Penelitian ini belum berhasil menemukan pengaruh atau hubungan antara diskriminasi perpajakan terhadap penggelapan pajak. Diskriminasi merupakan suatu kondisi dimana wajib pajak mendapatkan perlakukan yang tidak merata atau berbeda-beda oleh Ditjen Pajak. Contohnya seperti Peraturan Pemerintah Nomor 60 tahun 2010 tentang zakat dan sumbangan keagamaan yang sifatnya wajib dapat dikurangkan dari penghasilan bruto. Berdasarkan jawaban responden wajib pajak orang pribadi yang melakukan pekerjaan bebas, yang terdaftar di KPP Pratama Subang diskriminasi tidak berpengaruh terhadap perilaku seseorang dalam melakukan penggelapan pajak. Meskipun tingkat diskriminasi rendah kemungkinan seseorang melakukan penggelapan pajak sangat mungkin terjadi bukan karena perlakuan yang tidak merata atau berbeda-beda pada setiap wajib pajak, melainkan dapat disebabkan karena adanya kepentingan diri sendiri.

Hasil penelitian ini sejalan dengan penelitian yang dilakukan oleh Pratiwi dan Prabowo (2019) yang menyatakan bahwa tidak terdapat pengaruh antara diskriminasi pajak terhadap persepsi wajib pajak orang pribadi mengenai penggelapan pajak. Namun hasil penelitian ini tidak sejalan dengan penelitian yang dilakukan oleh Tumewu dan Wahyuni (2018) dalam penelitiannya menyatakan bahwa variabel diskriminasi berpengaruh terhadap penggelapan pajak.

\section{Pengaruh Pemahaman Perpajakan terhadap Penggelapan Pajak}

Dalam penelitian ini hasil data menunjukan bahwa nilai signifikansi sebesar sebesar 0,009 lebih kecil dari 0,05 $(0,009<0,05)$ dan nilai koefisien regresi sebesar -0,366 (bertada negatif), artinya bahwa variabel pemahaman perpajakan berpengaruh negatif dan signifikan terhadap penggelapan pajak. Dengan demikian maka hipotesis kelima (H5) diterima karena variabel pemahaman perpajakan berpengaruh negatif terhadap penggelapan pajak. Hal ini mengindikasikan bahwa semakin tinggi tingkat pemahaman wajib pajak mengenai perpajakan semakin rendah tingkat penggelapan pajak.

Berdasarkan data yang diperoleh dari jawaban wajib pajak orang pribadi yang melakukan pekerjaan bebas yang terdaftar di KPP Pratama Subang pemahaman perpajakan berpengaruh negatif terhadap penggelapan pajak. Artinya bahwa tingkat pemahaman wajib pajak pekerja bebas di KPP Pratama sudah tergolong tinggi. Apabila tingkat pengetahuan wajib pajak mengenai perpajakan seperti pemahaman tentang peraturan perundang-undangan, pemahaman tentang kewajiban wajib pajak dan pemahaman mengenai sanksi perpajakan tinggi maka wajib pajak akan menghindari untuk melakukan penggelapan pajak. Hal ini mencerminkan suatu iklim kepatuhan pajak adalah ketika seorang wajib pajak berusaha untuk memahami semua ketentuan dan peraturan perundang-undangan perpajakan. Berdasarkan pada pengetahuan dan pemahaman mengenai perpajakan yang dimilki wajib pajak tersebut, akan membuat wajib pajak enggan untuk melakukan penggelapan pajak.

Hasil penelitian ini sejalan dengan penelitian yang dilakukan oleh Ardiansyah 
(2017) bahwa pemahaman perpajakan berpengaruh negatif terhadap tindakan tax evasion. Semakin tinggi pemahaman perpajakan wajib pajak, maka kecenderungan tindakan untuk melakukan tindakan tax evasion oleh wajib pajak akan semakin berkurang. Hal juga diperkuat dengan penelitian yang dilakukan oleh Rachmadi (2014) bahwa pemahaman perpajakan yang dimiliki wajib pajak secara parsial berpengaruh signifikan terhadap persepsi wajib pajak atas perilaku penggelapan pajak. Hasil pengujian variabel pemahaman perpajakan menunjukkan adanya indikasi nilai yang negatif.

Namun hasil penelitian ini tidak sejalan dengan hasil penelitian yang dilakukan oleh Yezzie (2017) bahwa tidak terdapat pengaruh antara Pemahaman Perpajakan dengan persepsi wajib pajak mengenai etika penggelapan pajak/ tax evasion.

\section{Pengaruh Sanksi Perpajakan terhadap Penggelapan Pajak}

Dalam penelitian ini hasil analisis data menunjukan bahwa nilai signifikansi sebesar 0,454 lebih besar dari 0,05 $(0,454$ $>0,05)$ artinya bahwa variabel sanksi perpajakan tidak berpengaruh terhadap penggelapan pajak. Hal ini mengindikasikan bahwa tinggi dan rendahnya sanksi perpajakan tidak akan mempengaruhi tingkat penggelapan pajak.

Penelitian ini belum berhasill menemukan pengaruh atau hubungan antara sanksi perpajakan terhadap penggelapan pajak. Berdasarkan jawaban yang diperoleh dari wajib pajak orang pribadi yang terdaftar di KPP Patama Subang menunjukan hasil bahwa sanksi perpajakan tidak berpengaruh terhadap penggelapan pajak. Hal ini berarti meskipun sanksi perpajakan sudah diterapkan sesuai dengan undang-undang terhadap seluruh wajib pajak yang melanggar, tegas dan tidaknya sanksi perpajakan yang berlaku saat ini tidak akan mempengaruhi seseorang dalam melakukan penggelapan pajak, karena persepsi setiap orang mengenai tegas dan tidaknya sanksi juga berbeda-beda.

Hasil penelitian ini sejalan dengan hasil penelitian yang dilakukan oleh Yezzie
(2017) Sanksi Perpajakan tidak memiliki pengaruh terhadap persepsi wajib pajak mengenai etika penggelapan pajak/ Tax Evasion .Namun hasil penelitian ini tidak sejalan dengan hasil penelitian yang dilakukan oleh Sundari (2019) yang menyatakan bahwa sanksi perpajakan berpengaruh terhadap persepsi wajib pajak mengenai penggelapan pajak (tax evasion).

\section{Pengaruh Religiusitas terhadap Penggelapan Pajak}

Dalam penelitian ini hasil analisis data menunjukan bahwa nilai signifikansi sebesar 0,000 lebih kecil dari 0,05 (0,000 $<0,05)$ dan nilai koefisien regresi sebesar $-0,669$ (bertanda negatif), artinya bahwa variabel religiusitas berpengaruh negatif dan signifikan terhadap penggelapan pajak. Hal ini mengindikasikan bahwa semakin tinggi tingkat religiusitas seorang wajib pajak maka semakin rendah tingkat penggelapan pajak.

Berdasarkan data yang diperoleh dari jawaban wajib pajak orang pribadi yang terdaftar di KPP Pratama Subang, variabel religiusitas berpengaruh negatif terhadap penggelapan pajak. Artinya bahwa semakin tinggi tingkat religiusitas seorang wajib pajak maka semakin rendah tingkat penggelapan pajak yang akan dilakukan. Hal ini dapat dijelaskan bahwa sikap religiusitas yang ada dalam diri seseorang dapat mengendalikan setiap perbuatan yang dilakukannya. Ketika seseorang telah menghayati dan memahami ajaran agamanya, maka akan berpengaruh terhadap segala tindakan dan pandangan hidupnya. Sehingga dapat dikatakan bahwa jika seorang wajib pajak memilki tingkat religiusitas yang tinggi maka ia enggan atau tidak berniat untuk melakukan penggelapan pajak.

Hasil penelitian ini sejalan dengan penelitian yang dilakukan oleh Safitri (2018) menyatakan bahwa religiusitas berpengaruh negatif dan seginifikan terhadap penggelapan pajak. Jika seseorang memiliki religiusitas yang tinggi maka mereka akan cenderung memiliki tingkat kepatuhan perpajakan yang lebih tinggi. Penelitian tersebut didukung oleh penelitian yang dilakukan oleh Surahman dan Putra (2018) yang menyatakan bahwa 
religiusitas berpengaruh terhadap perspsi wajib pajak mengenai etika penggelapan pajak (tax evasion). Hasil ini menjelaskan bahwa jika religiusitas tinggi keyakinan yang kuat pada agama mengurangi sikap untuk melakukan kecurangan pajak. Namun hasil penelitian ini tidak sejalan dengan hasil penelitian yang dilakukan oleh Mutia (2015) bahwa religiusitas tidak berpengaruh pada etika penggelapan pajak.

\section{Pengaruh Love Of Money, Sistem Perpajakan, Keadilan Perpajakan, Diskriminasi Perpajakan, Pemahaman Perpajakan, Sanksi Perpajakan dan Religiusitas terhadap Penggelapan Pajak}

Berdasarkan hasil uji statistik yang telah dilakukan menunjukan, bahwa love of money, sistem perpajakan, keadilan perpajakan, diskriminasi perpajakan, pemahaman perpajakan, sanksi perpajakan dan religiusitas berpengarus secara simultan terhadap penggelapan pajak. Hal ini dibuktikan dari hasil uji statistik regresi yang menunjukan bahwa nilai sig. $F$ adalah sebesar 0,000 dimana nilai signifikansi tersebut kurang dari 0,05 $(0,000<0,000)$. Berdasarkan nilai Adjusted $R$ Square $\left(R^{2}\right)$ sebesar 0,374 yang menunjukan bahwa pengaruh love of money, sistem perpajakan, keadilan perpajakan, diskriminasi perpajakan, pemahaman perpajakan, sanski perpajakan dan religiusitas teradap penggelapan pajak hanya sebesar $37,4 \%$ sedangkan sisanya sebesar $62,6 \%$ biasa jadi berasar dari faktor lain yang tidak diteliti dalam penelitian ini. Maka dapat disimpulkan bahwa love of money, sistem perpajakan, keadilan perpajakan, diskriminasi perpajakan, pemahaman perpajakan, sanski perpajakan dan religiusitas secara bersama-sama atau simultan berpengaruh terhadap penggelapan pajak.

\section{KESIMPULAN}

Berdasarkan hasil penelitian yang dilakukan diatas, maka dapat disimpulkan sebagai berikut:
1. Secara parsial variabel love of money tidak berpengaruh terhadap variabel penggelapan pajak.

2. Secara parsial variabel sistem perpajakan tidak berpengaruh terhadap penggelapan pajak.

3. Secara parsial variabel keadilan perpajakan tidak berpengaruh terhadap penggelapan pajak.

4. Secara parsial variabel diskriminasi perpajakan tidak berpengaruh terhadap penggelapan pajak.

5. Secara parsial variabel pemahaman perpajakan berpengaruh negatif terhadap penggelapan pajak.

6. Secara parsial variabel sanksi perpajakan tidak berpengaruh terhadap penggelapan pajak.

7. Secara parsial variabel religiusitas berpengaruh negatif terhadap penggelapan pajak.

8. Secara simultan seluruh variabel love of money, sistem perpajakan, keadilan perpajakan, diskriminasi perpajakan, pemahaman perpajakan, sanski perpajakan dan religiusitas bersamasama atau secara simultan berpengaruh terhadap variabel penggelapan pajak.

\section{IMPLIKASI DAN KETERBATASAN Implikasi}

Peneliti berharap dengan adanya penelitian diharapkan para wajib pajak dapat meningkatkan kepatuhan dalam membayar pajak dan menghidari untuk melakukan penggelapan pajak. Penelitian ini juga diharapkan dapat memberikan kontribusi yang positif untuk Direktorat Jenderal Pajak sehingga penelitian ini dapat dijadikan acuan atau bahan pertimbangan dan evaluasi dalam menetapkan peraturan perpajakan agar setiap wajib pajak bisa merasakan keadilan dalam perpajakan dan kepada KPP Pratama Subang diharapakan penelitian ini dapat memberikan informasi untuk memperhatikan wajib pajak agar wajib pajak lebih memiliki kesadaran untuk 
membayar pajak dan menghindari tindakan penggelapan pajak.

Peneliti juga berharap penelitian ini dapat memberikan kontribusi kepada peneliti selanjutnya yang memiliki pengembangan penelitian yang berkaitan dengan seluruh variabel yang terdapat didalam penelitian ini.

\section{Keterbatasan}

Penelitian ini memiliki beberapa keterbatas yang mungkin dapat menimbulkan ketidakakuratan pada hasil penelitian ini, diantaranya yaitu:

1. Populasi penelitian ini adalah hanya wajib pajak yang terdaftar di KPP Pratama Subang, sehingga kesimpulan yang diuraikan hanya berlaku pada KPP Pratama subang saja dan tidak dapat digenerlisasikan untuk seluruh Kantor Pelayanan Pajak seluruh Indonesia.

2. Penelitian ini hanya dilakukan kepada wajib pajak orang pribadi pekerja bebas saja sehingga hasil analisis yang diperoleh hanya untuk wajib pajak orang pribadi bebas saja tidak berlaku untuk seluruh wajib pajak orang pribadi dan wajib pajak badan.

3. Adanya pandemi Covid-19 sedikit menghambat peneliti dalam melakukan penelitian dan permintaan data yang dibutuhkan.

\section{Saran}

Berdasarkan hasil penelitian yang telah dilakukan, maka peneliti memberi saran sebagai berikut:

1. Bagi peneliti selanjutnya:

a. Untuk peneliti selanjutnya diharapkan dapat menambah variabel lain yang diperkirakan dapat mempengaruhi seseorang untuk menggelapakan pajak, seperti pelayanan yang diberikan fiskus terhadap wajib pajak.

b. Untuk peneliti selanjutnya sebaiknya dapat menambah jumlah sampel dan memperluas ruang lingkup penelitian, misalnya pengambilan sampel yang dilakukan lebih dari satu KPP sehingga diharapkan hasil penelitian dapat disimpulkan secara luas. c. Ketika menggunakan survei dengan kuesioner sebaiknya lebih memperhatikan proses ketika reponden melakukan pengisian sehingga data yang diperoleh lebih akurat. Jika dimungkinkan lakukan wawancara untuk mengkonfirmasi seluruh jawaban yang diberikan oleh responden.

2. Bagi Wajib Pajak:

Untuk wajib pajak, peneliti menyarankan agar meningkatkan kepatuhan dan menghindari penggelapan pajak agar dapat meningkatkan penerimaan pajak. Karena pajak merupakan salah satu sumber pendapatan negara yang digunakan untuk melakukan pembangunan negara yang dapat kita rasakan manfaatnya bersama.

\section{DAFTAR PUSTAKA Undang-Undang}

Undang-undang No. 28 tahun 2007, pasal 39 ayat (1)

Undang-Undang No. 39 Tahun 1999, pasal 1 ayat (3)

Undang-Undang Nomor 16 Tahun 2000, pasal 1

\section{Buku}

Ghozali, I. 2018. Aplikasi Analisis Multivariate Dengan Program IBM SPSS 25 Edisi 9. Semarang: Badan Penerbit Universitas Diponegoro.

Mardiasmo. 2009. Perpajakan Edisi Revisi.Yogyakarta: Penerbit Andi.

Resmi, S. 2014. Perpajakan Teori dan Kasus. Jakarta: Salemba Empat.

Sekaran, Uma. 2011. Research Methods For Business (Metode Penelitian Untuk Bisnis). Jakarta: Salemba Empat.

Sugiyono. 2017. Metode Penelitian, Kuantitatif, Kualitatif dan R \& D. Bandung: Alfabeta 
Umiyati, Indah. Nurmalasari N. 2016. Statistika Penelitian Pengenalan Aplikasi SPSS dan Eviews.

\section{Jurnal}

Abrahams dan Kristanto.2016. "Persepsi Calon Wajib Pajak Dan Wajib

Pajak Terhadap Etika

Penggelapan Pajak Di Salatiga".

Berkala Akuntansi dan

Keuangan Indonesia Vol 1 No

1.Universitas Kristen Satya

Wacana.

Agus, Y.F., Umiyati, I., Kurniawan, A. ( 2019). Determinant and Mintigation Factors of Tax Evasion: Indonesia Evidence. Accounting Research journal of Autaatmadja. Vol. 3 (2): 226-246.

Ardiansyah, Y. 2017. Pengaruh keadilan, sistem self Assesment, pemahaman perpajakan, dan religiusitas terhadap tindakan tax evasion. Fakultas Ekonomi dan Bisnis. Universitas Hasnuddin: Makasar.

Asih, N.P.S.M., Dwiyanti, K.T. (2019). Pengaruh Love of Money. Machiavellian dan Equity Sensitivity Tehadap Persepsi Etika Penggelapan Pajak (Tx Evasion). Vol. 26: 1412-1435.

Basri, Y.M. (2015). Pengaruh Gender, Religiusitas dan Sikap Love OF Money Pada Persepsi Etika Penggelapan Pajak Mahasiswa Akuntansi. Jurnal IImiah Akuntansi dan Bisinis. Vol.10 (1).

Faradiza, S. A. (2018). Persepsi Keadilan, Sistem Perpajakan dan Diskriminasi Terhadap Etika Penggelapan Pajak. Jurnal IImu Akuntansi. Vol. 11 (1): 53-74.

Fatimah. S. \& Wardani, D. K. (2017). Faktor-Faktor Yang Mempengaruhi Penggelapan Pajak Di Kantor Pelayanan Pajak Pratama Temanggung. Akuntnasi Dewantara, 1(1),1-14
Indriyani, M., Nurlaela, S., Wahyuningsih, E.M. (2016). Pengaruh Keadilan, Sistem Perpajakan, Diskriminasi, dan Kemungkinan Terdeteksinya Kecurangan Terhadap Persepsi Wajib Pajak Orang Pribadi Mengenai Perilaku Tax Evasion. Seminar Nasional IENACO. ISSN: 2337-4349.

Maghfiroh, D., Diana, F. (2016). Persepsi Wajib Pajak Mengenai Pengaruh Keadilan, Sistem Perpajakan dan Sanksi Perpajakan Terhadap Penggelapan Pajak (survey terhadap UMKM di Berkasi). Vol.7 (1): 39-55.

Rachmadi, W., \& Zulaikha. (2014) Faktorfaktor yang mempengaruhi wajib pajak orang pribadi atas perilaku penggelapan pajak.Dipponegoro Journal of Accounting, 3(2), 1-9

Rosianti, C., Mangoting, Y. (2014). Pengaruh Money Ethics Terhadap Tax Evasion dengan Insrinsic dan Extrinsic Religiosity sebagai Variabel Moderating. Tax \& Accounting Review. Vol. 4 (1)

Safitri, A. (2018). Pengaruh Religiusitas dan Detection Rate Terhadap Penggelapan Pajak. Vol. 6 (1)

Silaen, C. (2015). Pengaruh Sistem Perpajakan, Diskriminasi, teknologi dan Informasi Terhadap persepsi wajin pajak mengenai etika penggelapan pajak (Tax Evasion). Jom FEKON, 2(2), 1-15

Sundari. (2019). Persepsi Wajib Pajak Mengenai Faktor Yang Mempengaruhi Penggelapan Pajak (Tax Evasion). Jurnal Kajian Akuntansi. Vol.3 (1): 5567.

Surahman, Wanda dan Ulinnuha Yudiansa Putra. "Faktor-Faktor Persepsi Wajib Pajak Terhadap Etika Penggelapan Pajak", 5(1), Jurnal REKSA: Rekayasa Keuangan, Syariah, dan Audit, 2018. 
Tumewu, J., Wahyuni, W. (2018). Persepsi Mahasiswa Fakultas Ekonoml Mengenai Penggelapan Pajak (Studi Kasus Pada Mahasiswa Fakultas Ekonomi Universitas Wijaya Kusuma Surabaya). VoL. 4 (1) : 37-57.

Yezzie, C. 2017. Pengaruh keadilan, sistem perpajakan, pemahaman perpajakan dan sanksi pajak terhadap persepsi wajib pajak mengenai etika penggelapan pajak (Tax Evasion). Skripsi. Fakultas Ekonomi dan Bisnis. Universitas Lampung: Bandar Lampung

\section{Skripsi}

Chaironisyah, R.W. (2018). Faktor-Faktor Yang Mempengaruhi Persepsi Wajib Pajak Orang Pribadi Mengenai Etika Atas Penggelapan Pajak (Tax Evasion). Skripsi. Fakultas Ekonomi Universitas Islam Negeri Maulana Malik Ibrahim: Malang

Fhyel, V.G. (2018). Pengaruh keadilan pajak, sistem perpajakan, diksriminasi, kemungkinan terdeteksinya kecurangan, pemeriksaan pajak, dan tarif pajak terhadap peggelapan pajak. Skripsi. Fakultas Ekonomi. Universitas Isam Indonesia: Yogyakarta.

Fadhilah, N. 2018. Pengaruh Religiusitas, persepsi mengenai sistem perpajakan dan keadilan terhadap persepsi wajib pajak tentang penggelapan pajak (tax evasion). Skripsi. Fakultas Ekonomi dan Bisnis Islam. Institut Agama Islam Negeri Surakarta.

Rahman, I.S. (2013). Pengaruh Keadilan, Sistem Perpajakan, Diskriminasi, dan Kemungkinan Terdeteksi Kecurangan Terhadap Persepsi
Wajib Pajak Mengenai Etika

Penggelapan Pajak (Tax

Evasion). Skripsi. Fakultas

Ekonomi dan Bisnis Universitas Islam Negeri Syarif Hidayatullah: Jakarta.

Sari, M. 2019. Pengaruh money ethics dan keadilan pajak terhadap tax evasion. Fakultas Ekonomi dan Bisnis.Universitas Islam Negeri Syarif Hidayatullah: Jakarta.

Suminarsasi, W., \& Supriyadi. (2011). Pengaruh Keadilan, Sistem Perpajakan, dan Diskriminasi Terhadap Persepsi Wajib Pajak Mengenai Etika Penggelapan Pajak (Tax Evasion). S2 Ilmu Akuntansi Universitas Gajah Mada.

\section{Website}

https://news.ddtc.co.id/apa-itu-pekeriaanbebas-21156

https://www.alinea.id/bisnis/ddtc-ada-limakebocoran-pajak-di-indonesia$\underline{\text { b1Xeo9iO8 }}$

https://www.pajak.go.id/sites/default/files/ 2019-

03/LAKIN\%20DJP\%202017.pdf

https://www.pajak.go.id/sites/default/files/ 2019-

04/LAKIN\%20DJP\%202016.pdf

https://www.pajak.go.id/sites/default/files/ 2019-

05/LAKIN\%20DJP\%202018.pdf

https://www.pajak.go.id/sites/default/files/ 2020-

02/LAKIN\%20DJP\%202019.pdf

https://www.pajakku.com/read/5d5bc6b46 a0a225035fca3e9/Apakah-Freelancesamadengan-Pekerjaan-Bebas 